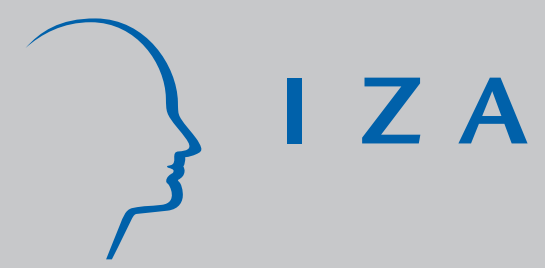

IZA DP No. 8306

Cross-National Differences in Wealth Portfolios at the Intensive Margin: Is There a Role for Policy?

Karina Doorley

Eva Sierminska

July 2014 


\title{
Cross-National Differences in Wealth Portfolios at the Intensive Margin: Is There a Role for Policy?
}

\author{
Karina Doorley \\ IZA and CEPS/INSTEAD
}

Eva Sierminska

CEPS/INSTEAD, DIW Berlin and IZA

Discussion Paper No. 8306
July 2014

IZA

P.O. Box 7240

53072 Bonn

Germany

Phone: +49-228-3894-0

Fax: +49-228-3894-180

E-mail: iza@iza.org

\begin{abstract}
Any opinions expressed here are those of the author(s) and not those of IZA. Research published in this series may include views on policy, but the institute itself takes no institutional policy positions. The IZA research network is committed to the IZA Guiding Principles of Research Integrity.

The Institute for the Study of Labor (IZA) in Bonn is a local and virtual international research center and a place of communication between science, politics and business. IZA is an independent nonprofit organization supported by Deutsche Post Foundation. The center is associated with the University of Bonn and offers a stimulating research environment through its international network, workshops and conferences, data service, project support, research visits and doctoral program. IZA engages in (i) original and internationally competitive research in all fields of labor economics, (ii) development of policy concepts, and (iii) dissemination of research results and concepts to the interested public.
\end{abstract}

IZA Discussion Papers often represent preliminary work and are circulated to encourage discussion. Citation of such a paper should account for its provisional character. A revised version may be available directly from the author. 


\title{
ABSTRACT
}

\section{Cross-National Differences in Wealth Portfolios at the Intensive Margin: Is There a Role for Policy?*}

\begin{abstract}
Using harmonized wealth data and a novel decomposition approach in this literature, we show that cohort effects exist in the income profiles of asset and debt portfolios for a sample of European countries, the U.S. and Canada. We find that the association between household wealth portfolios at the intensive margin (the level of assets) and household characteristics is different from that found at the extensive margin (the decision to own). Characteristics explain most of the cross-country differences in asset and debt levels, except for housing wealth, which displays large unexplained differences for both the under-50 and over-50 populations. However, there are cohort differences in the drivers of wealth levels. We observe that younger households' levels of wealth, given participation, may be more responsive to the institutional setting than mature households. Our findings have important implications, indicating a scope for policies which can promote or redirect investment in housing for both cohorts and which promote optimal portfolio allocation for mature households.
\end{abstract}

JEL Classification: $\quad \mathrm{G} 11, \mathrm{G} 21, \mathrm{~J} 10$

Keywords: $\quad$ wealth portfolios, decomposition, institutions, demographics

Corresponding author:

Eva Sierminska

CEPS/INSTEAD

3, avenue de la Fonte

L-4364 Esch-sur-Alzette

Luxembourg

E-mail: eva.sierminska@ceps.lu

\footnotetext{
* This research is part of the WealthPort project (Household Wealth Portfolios in a Comparative Perspective) supported by the Luxembourg 'Fonds National de la Recherche' (contract CORE C09/LM/04) and by core funding for CEPS/INSTEAD by the Ministry of Higher Education and Research of Luxembourg.
} 


\section{Introduction}

Assets have been playing an increasingly important role in measuring material well-being and in determining welfare program eligibility and take-up. The traditional approach to measuring economic well-being via income and labor market participation does not shed much light on other important aspects of welfare that can be measured via wealth. Wealth data can be used to study the way in which households acquire assets and the role they play in improving living standards and creating future opportunities for the owner and their children. In our previous work on wealth participation (Sierminska and Doorley (2013), we find that income and household composition explain a lot of the cross-country differences in asset and liability ownership for young households. For older households, education and household composition seem to be the main observable drivers. However, many of the cross-country differences in asset and liability ownership cannot be explained by observable household characteristics and may be attributable to the institutional framework, cultural or other differences. In the younger cohort, more of the cross-country differences in asset ownership seem unexplained and leave scope for policy interventions. For the older cohort it is the decision to hold debt which seems to leave more room for policy interventions. These findings are important as they give us an idea of how policy can affect household well-being through a different channel, namely wealth/debt ownership.

In this paper we continue our exploration of differences in wealth holdings across countries and focus on the level of assets and liabilities held. Once a household has decided to purchase a particular asset or liability, the next decision is how much to invest and whether or not to diversify the portfolio. This outcome will certainly depend on household characteristics as well as the institutional environment. Particularly for the elderly, the level of wealth may prove an important supplement to income, as current income may otherwise understate the amount of resources that are at hand to be used to maintain the desired level of economic well-being. ${ }^{1}$ For the young, wealth is important in ensuring future opportunities either for education, for their children, for retirement or as a safety net in case of an unexpected loss of income. Comparing these in a cross-national perspective and by cohort could lead to important policy implications.

\footnotetext{
${ }^{1}$ Income generating annuities (such as public and occupational pensions) may end with the death of a worker or spouse, while stocks or mutual funds can be passed on to children. Similarly, houses can be transferred to children, but their value is usually not captured in flow measures of economic well-being. Thus wealth may also be a better measure than income, both of the economic well-being of older persons and their ability to assist children through inter vivo transfers and bequests.
} 
The literature which advocates incorporating wealth into economic well-being measures is not abundant, but is certainly present. For example, several decades ago, Weisbrod and Hansen. (1968) proposed a wealth-augmented income definition, which led to different policy prescriptions than if the income alone measure is used. Due to the lack of reliable data on wealth, wealth has not been universally incorporated as proposed. More recently, due to additional data availability, there has been more interest in incorporating wealth in the measurement of economic well-being (e.g. Haveman and Wolff (2004); Brandolini et al. (2010)). Population aging has also raised questions about the long-term sustainability of pension systems and the need to assess the adequacy of savings for retirement through the study of the level and composition of assets with which households retire (e.g. Chiuri and Jappelli (2010), Gornick et al. (2009)). Nevertheless, the literature on incorporating wealth portfolios in the measurement of well-being is not abundant. Single or two-country studies are more common than cross-country comparisons due to data availability and difficulties in performing cross-national comparisons. Comparable cross-country data is not easily available. For example, the Survey of Health, Aging and Retirement in Europe (SHARE) captures individuals 50 and over. The Household Finance and Consumption Survey (HFCS) is available for euro-zone countries only. Another option for researchers is to rely on data in the Luxembourg Wealth Study, which has thoroughly examined and harmonized comparable and non-comparable components of wealth and has made a detailed study of country wealth components and institutions. This approach facilitates an insightful analysis of wealth portfolios across countries and allows comparisons across European, as well as non-European countries.

In this paper we follow the conceptual framework developed by the Luxembourg Wealth Study and apply it to independent data. We use two datasets that are used in the Household Finance and Consumption Survey (Italy and Spain) and are publicly available. In addition, we use data for Canada, Germany, Luxembourg and the United States, and thus are able to provide a unique view on household wealth portfolios in a cross-national perspective.

Our paper is novel in several ways. We use data for a unique set of countries and identify differences in their wealth portfolio levels and their determinants, focusing on differences between younger and older cohorts. We also introduce a novel way of decomposing asset levels across the distribution. In this way, we extend the literature methodologically by integrating methods typically used in discrimination analysis and labor studies to the study of differences in portfolio choices by applying a 'distributionally sensitive' approach to the decomposition of wealth levels. As the absolute levels of wealth across countries can be very different, we favor the distribution regression approach of Chernozhukov et al. (2009) over the Machado and Mata (2005) quantile regression methodology in order to highlight the extent of the wealth gap in the tails of each distribution. Correlating the 
"unexplained gap" in wealth levels across countries with institutional features of those countries allows us to make inferences about which policies promote asset and debt accumulation. Our focus is on the main assets and liabilities held by households; financial assets, main residence, investment real estate and debt, with a focus on mortgages and non-housing debt. ${ }^{2}$

Past research suggests a large role for institutions in explaining cross-national differences in portfolios. Christelis et al. (2012) find that characteristics play a small or negligible role in generating observed international differences for households 50 years and over. We show that the role of characteristics is more important than previously thought for particular assets and for the younger population.

We find that, given participation, cross-country differences in the level of financial assets and debt are largely driven by household characteristics. Real estate differences are, however, somewhat unexplained and could be attributable to cross-country differences in institutions. The level of wealth, given participation varies more in response to characteristics and other unobservables for the older cohort than the younger one for financial assets and risky assets. Mortgage debt levels across countries vary more for the young while we see mixed cross-country cohort results for non-housing debt. There is a strong effect of both characteristics and unexplained factors for both cohorts' levels of investment in real estate.

Our results suggest that institutional (or other unobserved) differences between countries predominantly affect the portfolio composition for younger households' levels of housing and mortgage debt. We take a preliminary look at some institutional features that could drive cross-country differences in these instruments. For older households, there are unexplained factors affecting levels of housing and financial assets at the top of this asset's distribution. These findings have important implications, indicating a scope for policies which can promote or redirect investment in housing for both cohorts, which target debt levels of young households and which promote optimal portfolio allocation for mature households.

In Section 2 we describe the data. Section 3 overviews the methods and provides basic descriptive statistics. The results are in Section 4 and Section 5 concludes.

\footnotetext{
${ }^{2}$ Although we do not take into account other factors such as different risks and returns for financial assets it has been shown that the majority of households have only a few types of assets. Less than $35 \%$ of households hold risky assets in the form of stocks or mutual funds and this number is much lower for the other countries.
} 


\section{Data}

In our sample, we use data for two North American countries: Canada and the US, and several European countries with varying institutional and welfare regimes: Germany, Italy, Luxembourg and Spain. At the time of data collection, all of these countries were experiencing low unemployment and positive GDP growth (Table 1) ${ }^{3}$. The data for Canada come from the 2005 Survey of Financial Security, for Germany the 2007 wealth module of the Socio-Economic Panel (SOEP), for Italy the 2008 Survey of Household Income and Wealth (SHIW), for Luxembourg from the 2007 wealth module of the PSELL-3/EUSILC, for Spain from the $2008 \mathrm{EFF}$ and the data for the United States come from the 2007 Survey of Consumer Finances (SCF).

The data contain detailed information on multiple income sources and financial and nonfinancial assets and debts. On the basis of this detailed information, we use the conceptual framework developed by the Luxembourg Wealth Study (described in Sierminska et al. (2006)) for creating harmonized variables of net worth (total assets: financial assets, principal residence, investment real estate and business equity minus liabilities: mortgages and non-housing debt) and income. Each of the wealth variables have been bottom and top coded at their 1\% and $99 \%$ levels to stop outliers from over-influencing our results and monetary variables have been converted to 2007 Euros using PPP and price indices.

The data are collected at the household level and individual level variables that are reported (such as age, gender, education) refer to the respondent/household head. In most cases, this person is the person most knowledgeable about household finances. Table A.1 shows the instruments that are available in each country. A comparison of this harmonized cross-country database to other sources (the HFCS data and the SHARE data for the over-50 population) is undertaken in Sierminska and Doorley (2013) and indicates that the LWS framework that we adopt to harmonize the different surveys across countries leads to similar participation rates in each of the instruments in the wealth portfolio.

\section{Methodology}

\footnotetext{
${ }^{3}$ One exception is Italy which registers a small decrease in GDP per capita in 2008, the year of data collection.
} 


\subsection{The level of wealth holdings}

Just as the decision to participate in different components of wealth portfolios may differ across countries (Sierminska and Doorley, 2013), so too may the level of holding, given participation, differ across countries. Table 3 describes the mean level of each portfolio instrument held in each country by the whole population. For financial assets, we find the largest mean holdings in the US. Canada and European countries have similar, lower levels with Luxembourg leading this group. Taking participation rates from table 2 into account, we can conclude that the differences with the US mainly stem both from higher participation and higher levels of this asset, given participation, in the US. In all of the countries examined, a large portion of wealth is held in the form of real estate. The highest levels can be observed in Luxembourg and Spain, with Canadian households holding the lowest levels of real estate. Debt levels are mostly composed of mortgages and are the highest in the US and Luxembourg.

In further panels of Table 3, the sample is partitioned by cohorts. For the younger cohort the patterns are similar to the ones described above. For the older cohort, in the bottom panel, we find differences, particularly when it comes to liabilities. In all countries, the level of debt drops but this is particularly true in Europe, where the participation rate also decreases substantially (Table 2). In Canada, we observe a drop in participation in debt as well as the level of debt, but not to such a great extent as that observed in Europe. This points to substantial cohort differences between the group of countries.

Figure 1 plots the aggregate level of each wealth component across the income distribution. To make holdings across countries more comparable, we scale each component by median annual income in each country. The top left panels in figure 1 show the level of Total Financial Assets held by households across the income distribution for the under-50 and over-50 population. The subsequent panels show Risky Assets, Principal Residence, Investment Real Estate, Mortgage Debt and Non Housing Debt.

There is a strong positive relationship documented between income and wealth. We also find this to be the case in our selection of countries when examining the relationship between income and the various components of the wealth portfolio. The level of each portfolio instrument increases as we move up the income distribution. In terms of total financial assets, the four European countries and Canada show similar holdings, which peak at around 4 times the median income at the very top of the income distribution for both the under-50 and over-50 population. In the U.S., the total financial asset holdings are similar to European levels up to median earnings, after which they shoot up to a maximum of 12 times median earnings for the top earners under 50 years of age and 32 times median 
earnings for the top earners over 50. So, not only is participation in financial assets higher in the U.S., but the level of financial assets given participation is higher, particularly at the top of the income distribution. Risky assets show a similar pattern, although the top level for the U.S. is less than half of that of total financial assets.

In terms of real estate, we find that the Spanish and Luxembourgish holdings of both principal property and investment real estate are consistently higher than those of other countries across the earnings distribution. Italian households hold higher levels of principal residence than Germany, the U.S. or Canada, while these four countries hold comparable levels of investment real estate across the income distribution, with the U.S. holding the least amount of either real estate asset.

Looking at debt, Spanish households hold the highest level of debt at the bottom of the income distribution, while the U.S., Germany and Luxembourg hold the most debt at the top of the income distribution. The vast majority of this debt is made up of mortgages in each country.

There are some noticeable differences between the sub-populations of under-50 and over50. The under-50 population holds higher levels of principal residence and total debt in each country, given participation. In the U.S., the highest level of financial assets is confined to the over-50 population at the top of the income distribution. However, the level of financial assets held by the under and over-50 population is similar throughout the rest of the income distribution.

\subsection{Decomposing the cross-country level of wealth holdings}

The previous discussion of wealth levels is based on raw distributions of wealth components. To study marginal distributions, that is, controlling for characteristics across countries across the distribution, we employ distribution regression (DR), following Chernozhukov et al. (2009) and Fortin et al. (2011). In practical terms, this involves running a series of probit models at each point in the distribution of each wealth component, $w$, in each country. The dependent variable is binary and takes the value of 1 if the household's wealth holding is less than or equal to $w$, and 0 otherwise, where $w$ takes the value of each point of the wealth distribution sequentially. Contrary to the Machado-Mata decomposition, which models conditional wealth levels at specific quantiles, DR models the conditional probability that a household has a wealth holding below $w$ in the distribution, hence mapping the whole conditional cumulative distribution function. We use demographics, labor market status, marital status and education to model the level of wealth 
held. ${ }^{4}$ Using DR, we predict the probability that each household has a wealth holding below each $w$ in the distribution. This allows us to construct predicted cumulative distribution functions for each component of the wealth portfolio. We can also predict what this probability would be if the household accumulated wealth in the same way as a similar household in the US, i.e., if the model coefficients of each country were identical to those of the US model. This allows us to construct counterfactual cumulative distribution functions for each instrument in the wealth portfolio. We employ a Blinder-Oaxaca style decomposition of the marginal wealth distributions in each country (using the US as the baseline) to identify what portion of the difference between wealth distributions is due to characteristics and what portion is unexplained, or due to institutional or other unobserved differences.

Starting from estimates of the conditional distribution of each wealth component $(w)$ in country $j$, given household characteristics $(X)$, we recover estimates of the marginal distribution by integration of the conditional distributions over household characteristics:

$$
F_{j}^{j}(w)=\int_{\Omega_{X}} F^{j}(w \mid X) h_{j}(X) d X
$$

where $F^{j}(\cdot \mid X)$ is the conditional cumulative wealth distribution function for household characteristics $X$ in country $j$ and $h_{j}$ is the density distribution of household characteristics for this country.

We can separate the household characteristics from the conditional cumulative wealth distribution to construct counterfactual wealth distributions for country $j$, if they chose wealth portfolios in the same way as similar U.S. households (i.e. if the institutional setting in country $j$ was that of the U.S.). For example:

$$
F_{j}^{u s}(w)=\int_{\Omega_{X}} F^{u s}(w \mid X) h_{j}(X) d X
$$

estimates the counterfactual wealth distribution that would prevail in country $j$ if portfolio decisions followed the U.S. model, where $F^{u s}(\cdot \mid X)$ is the conditional cumulative wealth distribution function for household characteristics $X$ in the U.S. and $h_{j}$ is the density distribution of household characteristics in country $j$.

Estimates are obtained by replacing $F^{u s}(\cdot \mid X)$ by estimates $\hat{F}^{u s}(\cdot \mid X)$ in equation (2), and

\footnotetext{
${ }^{4}$ The variable list can be seen in tables A.3 - A.5
} 
by averaging over our sample of $N$ households $w$ in country $j$ :

$$
\hat{F}_{j}^{u s}(w)=\sum_{t=1}^{N_{j}} \hat{F}^{u s}\left(w \mid x_{t}\right)
$$

In order to represent the explained and unexplained gaps graphically in terms of the level of each asset, we invert the conditional and counterfactual distributions to obtain quantiles. ${ }^{5}$ Consider $Q_{j, \tau}^{u s}(w)$, the $\tau$ th quantile of the counterfactual distribution $F_{j}^{u s}(w)$. The estimated counterfactual quantile is:

$$
\hat{Q}_{j, \tau}^{u s}(w)=\left[\hat{F}_{j, \tau}^{u s}(w)\right]^{-1}
$$

Performing an Oaxaca-Blinder style decomposition to isolate the difference in wealth distributions that is due to household characteristics and the difference that is unexplained, or can be attributed to institutional differences and unobservables across countries, we have:

$$
\begin{array}{r}
Q_{u s, \tau}^{u s}(w)-Q_{j, \tau}^{j}(w)= \\
{\left[\hat{Q}_{u s, \tau}^{u s}(w)\right]-\left[\hat{Q}_{j, \tau}^{u s}(w)\right]+\left[\hat{Q}_{j, \tau}^{u s}(w)\right]-\left[\hat{Q}_{j, \tau}^{j}(w)\right]}
\end{array}
$$

The first expression on the right hand side of equation 5 identifies the unexplained contribution to differences in wealth levels, while the second expression identifies the difference that can be accounted for by different household characteristics across countries. We perform this decomposition for each wealth component in each country.

\section{Results}

\subsection{Country differences in asset level determinants}

To model country differences in asset levels, we use the distribution regression approach (DR) elaborated in section 3. Model results for the median of each asset's distribution for the population under 50 years of age are displayed in Tables A.3 to A.5. Interpreting

\footnotetext{
${ }^{5}$ See Fortin et al. (2011) for a more detailed discussion of this inversion.
} 
these coefficients is as follows. The negative coefficient on age for the US portfolio of total financial assets shows that, as age increases, households are less likely to hold less than the median level of this asset, i.e. age has the traditionally positive effect on this measure of wealth. We generally see similar effects of age across countries, except for non-housing debt, which decreases with age. In all countries, a male or more educated household head increases wealth levels compared to a female or low educated household head.

There are differences in the direction of the effect of marital status, labor market status, number of children and income across countries. In our reference country, the U.S., we find that being married (compared to single or divorced), having no children, being employed or self-employed and having higher income and other wealth all positively affect wealth holdings.

\subsection{Decomposition of wealth levels across the distribution}

To begin examining wealth level differences across the distribution, we first plot (Figure 2) the predicted cumulative distributions of each item in the wealth portfolio by country for the younger cohort. These graphs show the distribution of the level of wealth conditional on participation. The monetary value of the relevant wealth component is scaled by the median income in each country to facilitate cross-country comparisons. The fit of the DR model is excellent as the predicted distributions follow the actual wealth distributions very closely (results available from authors upon request).

From the top panels of figure 2, we note that the level of financial assets and risky assets is highest and affects a larger share of the population in the U.S. (in line with our observations in figure 1). The level of these assets is lower and more similar in the other countries. Levels of investment real estate and principal residence are highest in the European countries, particularly in Spain and Luxembourg and lowest in the US and Canada. Mortgage debt is highest in Spain and lowest in the US and Canada. These phenomena are likely to be related to the high housing prices in Spain and Luxembourg, relative to income, and the high availability of loans in Spain in pre-crisis times. Non-housing debt levels are similar across countries. 


\subsubsection{Decomposition example}

To graphically represent the decomposition elaborated in equation 5 , in figure 3 , we present a graphical example of the decomposition. Here, we show the conditional distributions of principal residence, given participation, for the younger cohort for the U.S. and Germany. The U.S. has lower levels of principal residence than Germany, as evidenced by the fact that the "U.S." line is consistently closer to the vertical axis than the line for Germany. Only about $20 \%$ of U.S. households hold a level of principal residence that is more than 10 times the median income of the country. By contrast, at least $50 \%$ of German households hold a level of principal residence that is more than 10 times the median income of the country. The counterfactual distribution of principal residence in Germany, if the institutional/other settings were the same as the U.S., is shown by the line "Germany with U.S. coefficients". The horizontal difference between the lines "US" and "Germany with U.S. coefficients" shows the difference in the level of principal residence that is explained by the different characteristics of German and U.S. households. The horizontal difference between the lines "Germany with U.S. coefficients" and "Germany" is the unexplained/institutional gap. In this example, the unexplained/institutional gap is small. Thus the characteristics are able to explains almost all of the difference in principal residence levels between these two countries for the under-50 cohort.

In what follows, we will graph just these horizontal gaps in order to facilitate interpretation.

\subsubsection{Components of wealth portfolios}

The main components of wealth portfolios and, therefore, those examined in detail in the remainder of this paper, include financial assets and non-financial assets and liabilities. In our case, in additional to total financial assets, we are also able to distingush a subcomponent of risky assets for some countries. Non-financial assets refer to real estate and businesses. Here we focus on the main residence and investment real estate. The largest share of liabilities is composed of mortgages and non-housing debt. Table 4 shows the proportion each instrument in the portfolio represents compared to total assets. As discussed, a majority of wealth is held in the form of real estate. Across countries, 52\% of total assets are composed of principal residence while $14 \%$ are investment real estate. These shares are even larger for the younger than the older cohort. For the older cohort in the US and Canada, a larger share is held in financial assets (40\% for the US and 22\% in Canada). We do not see a very large change across cohorts in wealth composition in European countries indicating that most of their wealth remains locked in real estate, 
although we do see diminishing levels of debt compared to total assets.

Total financial assets First, we examine total financial assets. Figure 4 shows the total gap between the level of total financial assets in the U.S. and each of the other countries. This total gap is decomposed into a characteristic gap and an institutional gap. The total gap is always positive meaning that the U.S. has higher levels of total financial assets, given participation, than each of the other countries. This gap is largest at the top of the total financial asset distribution and is largely composed of characteristic differences. In fact, the institutional gap between the U.S. and the other countries is negative, meaning that the total gap would even be larger if the European countries and Canada did not have certain institutional (or other) features which encouraged investment in financial assets. This institutional gap, present particularly at the top of the distribution, is larger for the older cohort. Taxation, investment incentives and differences in the culture of inheritances could be some of the factors affecting these differences.

In comparison to the participation decision in financial assets, for which characteristics explain just a small part of the cross-country gap (Sierminska and Doorley (2013)), the level of financial assets held, conditional on participation, is almost entirely explained by household characteristics although there are some unexplained factors driving the gap at the top of the asset distribution suggesting that, for most households, once they make the decision to own financial assets, the levels are mostly driven by their family and economic characteristics.

Risky Assets Risky assets are an important component driving the results for financial assets at the top of the distribution. We find a similar characteristics gap as for total financial assets throughout the distribution and a virtually non-existent institutional gap, except in Canada, in Table 5. This gap suggests that there is an unobserved reason for Canadian households to increase their risky asset holdings, particularly older households at the top of the risky asset distribution. The participation gap in risky assets was also found to be driven by characteristics mostly income and education (Sierminska and Doorley (2013)).

Principal Residence As we saw in table 2, main home ownership is higher in the U.S. that in every other country examined except Spain. We turn next to the difference in the distribution of principal residence, given participation. From Figure 6, the total gap between the U.S. distribution and the European countries is negative while there is a small positive gap between the U.S. and Canada. This implies that, given participation, the U.S. holds lower levels of principal residence (or that housing is cheaper relative to the median 
income) than the European countries and a slightly higher level than Canada (towards the top of the distribution). Unlike other components of the wealth portfolio, these gaps are similar for both cohorts. A negative characteristic gap makes up most of this difference indicating that U.S. households hold less valuable principal residences due in large part to their household characteristics. This could include their level of investment in other assets. However, there is also a negative institutional gap for Germany, Italy, Spain and Canada indicating that households in these countries also hold higher levels of wealth in their principal residence (relative to their income) due to institutional or other features of their country compared to the US.

Investment Real Estate The results for the difference in the level of investment real estate between the U.S. and the other countries in Figure 7 indicate a small, but negative gap in every country but Canada. The gap is larger for the older cohort and is the largest in Spain and Luxembourg. For most countries, the total gap is composed of a negative characteristics gap and a smaller negative unexplained gap indicating that households from other countries invest in higher levels of real estate than US households due both to household characteristics and to institutional or other country features. One exception is Canada which displays a positive characteristics gap.

To compare these results to the participation decision (Sierminska and Doorley (2013), we find that, in both the participation and levels decision, a mix of explained and unexplained factors contribute to the cross country gaps.

Mortgage Debt Mortgages are a very interesting case (Figure 8). The total gap in mortgage debt levels between the U.S. and the European countries is negative for the younger cohort, as is the value of real estate, and, except for Canada, is smaller for the older cohort. There is a small positive gap between the U.S. and Canada at the top of the distribution and at the bottom of the distribution between the U.S. and Italy and the U.S and Luxembourg. Most of these gaps are unexplained and negative (in contrast to the participation decision for this group), indicating that U.S. households hold lower mortgage debt levels than European households due to the institutional environment or other unobserved factors (Luxembourg is an exception). There is also a negative institutional gap between the U.S. and Canada but a larger positive characteristic gap between these countries leads to a small positive overall gap.

For the older cohort, the total gaps are smaller indicating that cross-country differences in mortgage levels are more similar across countries for older households than younger households. The charactristic gap in Germany and Canada remains positive. 
Non-housing Debt Finally, we turn to non-housing debt (Figure 9). Here we observe two patterns: a negative gap between the US and Germany and Spain, increasing at the top of the distribution and a positive almost non-existant gap for Italy and Canada. The gaps become larger for the older cohort for Germany and Spain and smaller for Italy and Canada. In all countries, except Germany, the characteristic effect dominates the unexplained effect. In Germany, for the younger cohort the institutional gap is driving the results and is still present for the older cohort.

\subsubsection{Cohort differences}

Comparing the results for the two cohorts we find total gaps and characteristic gaps to be larger for the older cohort's level of financial assets across countries. Unexplained/institutional gaps are more important in determining the share of financial assets in the younger cohort's portfolio (although, they are smaller in level terms). This contrasts to the participation decision, for which the characteristic and institutional gaps are larger for the younger cohort. The gaps for both cohorts are larger at the top of the distribution, thus only the very rich seem to be sensitive to the institutional set-up, possibly via tax incentives.

Housing is a big part of the wealth portfolio, often reaching about two thirds of total assets. Thus, a specific housing enhancing institutional policy can potentially play a large role in wealth accumulation. We find similar gaps in the level of principal residence for the two cohorts. However, the older cohort shows larger between-country differences in the distribution of investment real estate. We find institutional effects and other unobservables to play a similar role in the housing wealth for the two cohorts leaving scope for more targeted policy overall.

On the other hand, we find a smaller role of institutions for the older than the younger cohort for the level of mortgage debt. As the younger cohort have higher average levels of mortgage debt than the older cohort (Table 3), this is unsurprising. Given the decision to take out a mortgage, the amount borrowed may be more sensitive to lending terms or other institutional factors for the younger cohort.

\subsection{The intensive vs. the extensive margin of investment}

Comparing asset participation rates across countries, as we do in Sierminska and Doorley (2013), informs us of the prevalence of each instrument in the population. The decision to own or not to own can be considered as the extensive margin of investment. In this pa- 
per, we examine the intensive margin or the magnitude of investment in each instrument separately by country and deduce the differences in relative investment levels across countries. This provides us with a more complete picture of portfolios and shows us the extent to which wealth could be used to supplement well-being cross-nationally. For example, large unexplained differences in housing levels indicate there are probably differences in housing affordability. Large characteristic gaps for most instruments indicate that most of the cross-national variation in these can be explained. Unexplained gaps suggest there is room for policy intervention via for example, tax rates. Here, we summarize our findings for the main wealth instruments: financial assets, principal residence, investment real estate and mortgage debt and compare the results to those on the participation decision from (Sierminska and Doorley (2013)).

The participation gap in financial assets between the US and the other countries is largely unexplained. By contrast, almost all of the levels gap, given participation, is explained by characteristics, with institutions contributing a small negative gap at the top of the income distribution, indicating that institutions are more conducive to investing in high levels of financial assets for high income people outside the US.

In terms of risky assets, both the participation and the amount that is invested are mostly driven by characteristics (income and education for the participation decision). Education is often used as a proxy for financial literacy and, as such, could serve as a proxy of financial sophistication, leading households to invest in risky assets that are known, on average, to yield higher returns.

The cross-national differences in housing wealth (given participation) are explained by differences in characteristics to a large extent. The value of this housing in the U.S. is also lower than those of similar households in most countries (except Canada) due to institutional or other features. Thus, in the US, home value represents a lower proportion of the total asset portfolio than in Europe. Homeownership is also more prevalent in the U.S than in the other countries, but this is due once again to characteristics. The institutional effect is also negative for homeownership indicating that Canadian and European households would still have higher homeownership rates than the US if they had the same characteristics.

The U.S. has higher participation in mortgage debt than either Canada or the European countries. This participation gap is a mixture between explained and unexplained components. The unexplained part of the gap is dominant and larger for the older cohort than for the younger one. Although there is higher prevalence of mortgage debt in the US, the levels are higher in European countries and this is unexplained by characteristics, especially for the younger cohort. The gaps are negative and unexplained for the younger 
cohort (except in Luxembourg). The variation in these outcomes suggest there are a lot of institutional differences at play here (as discussed $\mathrm{n}$ the next section) and scope for policy related to debt take-up for the older cohort, but to a smaller extent at the intensive margin (the amount, given take-up). ${ }^{6}$

The participation gaps for non-housing debt are large (except for Canada), largely unexplained and present for both cohorts. For levels this is also true except for the fact that the gaps are driven by characteristics for the older cohort. Thus once households commit to having debt, the levels depend on household characteristics. The decision to have debt in the first place may stem from institutional or cultural factors.

\subsection{The role of institutions and culture}

In this section, we take a more in-depth look at institutional differences in the countries in our sample and try to draw a link between the sign and magnitude of the unexplained (institutional) gaps in wealth levels across countries and the institutional setting. Institutional differences across countries may be responsible for different investment patterns and an understanding of which institutions drive investment decisions will be invaluable to policymakers who are, for example, interested in further market integration at the EU level or, indeed, in promoting certain types of investment over others depending on the labor market, dependency ratio and other characteristics of the country concerned.

Ideally, we would like to include institutional measures in our decomposition framework but, for compatibility with a cross-country decomposition, we would need regional variation in these measures within a country so that the measure can be incorporated into each country's wealth level regressions. In the same way as we can draw inferences about the effect of household composition and labor market status on wealth accumulation, the coefficients on these institutional variables would then also tell us something about how they affect wealth accumulation. However, in the absence of regional variation in most institions or of data relating to any suitable regional variations, we limit ourselves to robust bivariate linear regressions of the unexplained gap in wealth levels at the median for each component of wealth on country institutional features.

In our analysis, we use a number of indices, summarized in Table 5. A number of these directly relate to the economy. The Financial Development Index, is a score for the breadth, depth and efficiency of each country's financial system and capital markets

\footnotetext{
${ }^{6}$ For the older cohort, pension income may have a large effect on the extensive margin **ES: Karina, can we check this-if strong effect of income for 50+-stronger than for the young?***, as it determines their needs for debt.
} 
(Bilodeau (2008)). Next, the Index of Economic Freedom, measures the economic freedom in each country, with higher scores indicating lower government interference in the economy (Kane (2007)). The banking regulation index measures the degree of banking regulation in each country, including enforcement power (Andrews et al. (2011)). The marginal tax rate measures the tax due on an extra dollar of income for a single person earning either $67 \%$ or $167 \%$ of the average wage. Household equity in pensions measures the net equity (in euros per capita) of households in life insurance and pension funds reserves. Dividend tax is a measure of the top rate of tax on corporate dividends. Tax as a percentage of GDP meaures current taxes on income, wealth, etc., as a proportion of GDP. The same ratio for capital tax is also used.

As our analysis looks at a number of aspects of the housing market, principal residence, investment real estate and mortgage debt, we also use three features of mortgages in each country (see Andrews et al. (2011)): the maximum loan-to-value (LTV) ratio, the prevalence of fixed rate mortgages and the typical maturity rate of mortgages. Lastly, we use a measure of mathematical literacy from the PISA project as a proxy for the education system.

The results of these simple regressions are depicted in Table 6 for five components of the wealth portfolio. We exclude Risky Assets from this analysis as we do not have information on this wealth component in either Germany or Luxembourg.

The dependent variable is the unexplained gap in the level of each component of the wealth portfolio in turn. To visualise this gap, we can look to figure 3. The unexplained gap in principal residence between Germany and the US is the horizontal distance between the lines "Germany with US coefficients" and "Germany" or, more formally:

$$
\left[\hat{Q}_{u s, \tau}^{j}(w)\right]-\left[\hat{Q}_{j, \tau}^{j}(w)\right]
$$

For the purpose of this exercise and to facilitate interpretation, we multiply this gap by -1 . That is, we define:

$$
g a p=\left[\hat{Q}_{j, \tau}^{j}(w)\right]-\left[\hat{Q}_{j, \tau}^{u s}(w)\right]
$$

Our simple model becomes:

$$
g \hat{a} p=\alpha+\beta I
$$


where $I$ takes the value of each of the institutional indices in turn. A positive $\beta$ in Table 6 indicates a positive correlation between the unexplained gap in the level of a particular wealth component (and, therefore, a positive correlation between the level of a particular wealth component, given household characteristics) and the institutional index. We summarise the results by index below.

Financial Development This index measures the breadth, depth and efficiency of each country's financial system across a range of factors including the institutional environment, financial stability, banking and non-banking financial services, financial markets and financial access. Regressing the unexplained gap in the level of either type of housing (principal residence or investment real estate) on this index yields negative coefficients both for households under 50 years of age and over. An increase of 1 point in the financial development index is associated with a decrease in the level of principal residence or investment real estate of about twice the median income, with a larger effect for older households. Financial development, therefore, seems to be negatively associated with homeownsership. It is possible that countries with more developed and stable financial systems substite real estate investment for investment in more liquid financial assets although we see no direct evidence of this in our regression for total financial assets. It is also possible that financial development leads to a lower need for precautionary savings/investments altogether.

Economic Freedom We observe similar patterns with the index of Economic Freedom. Economic Freedom measures the degree of government interference in each economy and captures business freedom, trade freedom, fiscal freedom, freedom from government, monetary freedom, investment freedom, financial freedom, property rights freedom, freedom from corurption and labor freedom. The higher this index is, the less the government interferes in the economy. As such, we might expect more economically free countries to provide less subsidies for housing. Our results confirm this theory with economic freedom associated with less investment in housing.

Bank Regulation Banking regulation measures the degree of banking regulation, including enforcement power, in each country. We expect that countries with higher levels of bank regulation will have stricter lending policies but, also, more banking stability. This may lead to higher trust in institutions. We observe that the degree of regulation is posivitely correlated with the level of mortgage debt, particularly for the over-50 population which is in line with the idea that more regulation promotes lending through its effect 
on stability rather than hindering it through its effect on regulatory capital adequacy ratios and loan to value measures. We also observe a negative correlation between the level of real estate held, particularly investment real estate, and the degree of banking regulation which could indicate that lending for this purpose is curtailed in more regulated banking systems or that higher trust in institutions encourages households to invest in financial products more than in real estate.

Tax Rate We also use a number of tax measures in our analysis. The marginal tax rate measures the tax due on an extra dollar of income for a single person earning either $67 \%$ or $167 \%$ of the average wage. Higher marginal tax rates indicate less disposable income and less incentive to earn investment income as more of it will have to be paid over in tax. However, we find little association between the marginal tax rate and the various portfolio instruments, except for a positive correlation between the marginal tax rate for low earners and investment real estate and non-housing debt. The dividend tax rate measures the net top statutory rate to be paid at the shareholder level and should indicate how attractive/profitable shareholdings are in each country. We find no association between the top rate of dividend taxation and the level of total financial assets, but there is a negative relationship between this tax rate and housing wealth. Tax as a proportion of GDP and capital tax as a proportion of GDP provide markers for how redistributive the tax-benefit system in a country is. It is unclear how we might expect these indices to be related to wealth accumulation as redistribution may encourage poorer households to invest while discouraging richer households. In general, we find a positive association between these measures and the level of assets and mortgages held, indicating that the net result of redistribution may be more wealth accumulation.

Household equity in life insurance and pension fund reserves This measure indicates how prepared households are for retirement and/or unexpected losses of earnings. We expect that higher equity will result in lower wealth accumulation for precautionary reasons. We do indeed find a negative correlation between this measure and the level of assets (and debt) held by households.

Mortgage Characteristics We use three measures relating to mortgages in each country: the typical maturity length, the prevalence of fixed rate mortgages and the maximum loan-to-value ratio. We find that longer mortgage maturities are associated with lower levels of real estate wealth. That is, the lower the monthly repayments (through longer mortgage terms) the lower the value of housing held. This could be due to the fact 
that longer mortgage terms mean higher overall interest payments, increasing the total cost of real estate and making it less affordable.

Mathematical literacy We use a measure of mathematical literacy from the 2006 PISA test which evaluates the mathematical literacy of 15 year olds across countries in a harmonized way. Financial literacy has been found to be negatively associated with non-housing debt (Lusardi and Tufano (2009)) and positively associated with mortgage participation (Brown and Graf (2012)). However, we find no association between mathematical literacy and any of the portfolio instruments.

\section{Conclusions}

In this paper, we apply novel techniques to the analysis of wealth portfolios. We decompose the wealth portfolio at the intensive margin (given participation in a particular instrument) for a selection of assets and liabilities across countries. We focus on households whose head is under 50 years of age and compare them to those over 50 years old. In this paper, we have considered the level of wealth held, given participation and compared our findings to our previous results relating to the participation decision itself.

We first showed the positive relationship between income and asset and liability levels for various components of the wealth portfolio. US households are found to have higher levels of financial and risky assets than European or Canadian households, especially at the top of the income distribution. European households, conversely, have higher levels of real estate investments than US households throughout the income distribution. The debt-income profile of our sample of countries shows that, among poor household, it is the Spanish that have the highest level of debt while, among rich households, US, Luxembourgish and German households have the highest level of debt.

Looking at the determinants of these differences, we see that the difference in the level of financial assets between the US, Canada and Europe is largely driven by household characteristics. There is actually a small negative unexplained effect which indicates that European and Canadian households would have higher levels of financial assets than US households if their characteristics were the same. Differences in levels of real estate across countries are found to be only partly explained with European and Canadian households holding higher levels of housing wealth than US households for unexplained reasons, likely linked to the institutional environment. We see similar patterns for levels of debt (primarily mortgage debt) with the European countries and Canada holding higher lev- 
els of debt than US households for reasons unrelated to their household characteristics. Most of the unexplained cross-country differences that we observe occur at the top of the asset/debt distribution, indicating that if institutional factors are behind them, investment policies may be most effective if targeted at wealthier households.

Cohort effects exist in the cross-country differences in asset levels. Cross-country differences in asset and liability levels are generally larger for the older cohort but most of these differences are explained by household characteristics. The unexplained gap in investment and borrowing levels is larger for the younger cohort than the older cohort. This indicates than levels of investment and borrowing for younger households may be more influenced by the instituional environment. This contrasts to the participation decision across cohorts. Unexplained participation differences in assets are found to be larger for the younger cohort while unexplained differences in participation rates for debt are found to be larger for the older cohort. It seems that, once the decision to invest or to borrow is taken, the level of investment made by younger households is more sensitive to institutions, culture or other country differences than older households.

In an attempt to explain part of the unexplained differences in asset and liability levels across countries, we examined the association between unexplained wealth gaps and a number of institutional indices. We found some consistent patterns with financial development, economic freedom, mortgage maturity and bank regulation negatively correlated with housing wealth. Housing wealth is the instrument for which we found the largest unexplained differences across countries so these results indicate that the institutional environment may be a dirver of cross-country investment patterns in this instrument.

Clearly, the degree of participation in wealth and the level of wealth held across countries vary widely and for many observable and unobservable reasons. The incorporation of some measure of wealth into traditional poverty or well-being measures may, therefore, change the conclusions of such measure about at-risk populations, particularly older households. This is something that can be expected to happen in the future as the quality of data on wealth improves.

Future research, could try to control for observable institutional factors to examine to what degree these affect the unexplained gap in portfolio participation and levels across countries. 


\section{References}

Andrews, D., Sánchez, A. C., and Åsa Johansson (2011). Housing markets and structural policies in oecd countries. OECD Economics Department Working Papers 836, OECD Publishing. 16

Bilodeau, J., editor (2008). The Financial Development Report 2008. World Economic Forum,. 16

Brandolini, A., Magri, S., and Smeeding, T. M. (2010). Asset-based measurement of poverty. Journal of Policy Analysis and Management, 29(2):267-284. 2

Brown, M. and Graf, R. (2012). Financial literacy, household investment and household debt: Evidence from switzerland. Working Papers on Finance 1301, University of St. Gallen, School of Finance. 19

Chernozhukov, V., Fernandez-Val, I., and Melly, B. (2009). Inference on counterfactual distributions. CeMMAP working papers CWP09/09, Centre for Microdata Methods and Practice, Institute for Fiscal Studies. 2, 6

Chiuri, M. and Jappelli, T. (2010). Do the elderly reduce housing equity? an international comparison. Journal of Population Economics, 23(2):643-663. 2

Christelis, D., Georgarakos, D., and Haliassos, M. (2012). Differences in portfolios across countries: Economic environment or household characteristics? The Review of Economics and Statistics, (forthcoming). 3

Fortin, N., Lemieux, T., and Firpo, S. (2011). Decomposition Methods in Economics, volume 4 of Handbook of Labor Economics, chapter 1, pages 1-102. Elsevier. 6, 8

Gornick, J. C., Sierminska, E., and Smeeding, T. M. (2009). The income and wealth packages of older women in cross-national perspective. The Journals of Gerontology: Social Sciences, Volume 64B, Number 3, May 2009:402-414. 2

Haveman, R. and Wolff, E. (2004). The concept and measurement of asset poverty: Levels, trends and composition for the U.S., 1983 2001. Journal of Economic Inequality, 2(2):145-169. 2

Kane, T. (2007). 2007 Index of Economic Freedom. Washington, D.C. and New York: Heritage oundation and the Wall street Journal. 16

Lusardi, A. and Tufano, P. (2009). Debt literacy, financial experiences, and overindebtedness. NBER Working Papers 14808, National Bureau of Economic Research, Inc. 19 
Machado, J. A. F. and Mata, J. (2005). Counterfactual decomposition of changes in wage distributions using quantile regression. Journal of Applied Econometrics, 20:445-465. 2

Sierminska, E., Brandolini, A., and Smeeding, T. (2006). The Luxembourg Wealth Study: A cross-country comparable database for household wealth research. Journal of Economic Inequality, 4(3):375-383. 4

Sierminska, E. and Doorley, K. (2013). To own or not to own? household portfolios, demographics and institutions in a cross-national perspective. IZA Discussion Papers 7734, Institute for the Study of Labor (IZA). 1, 4, 11, 12, 14

Weisbrod, B. A. and Hansen., W. L. (1968). An income-net worth approach to measuring economic welfare. . American Economic Review, 58(5):1315-1329. 2 


\section{Tables and Figures}

Table 1: Country sample macroeconomic conditions.

\begin{tabular}{|c|c|c|c|c|c|c|c|c|}
\hline \multicolumn{9}{|c|}{ A. Real GDP growth } \\
\hline & 2002 & 2003 & 2004 & 2005 & 2006 & 2007 & 2008 & 2009 \\
\hline Canada & 2.9 & 1.9 & 3.1 & 3.0 & 2.9 & 2.5 & 0.4 & -2.7 \\
\hline Germany & 0.0 & -0.2 & 0.7 & 0.9 & 3.4 & 2.6 & 1.0 & -4.9 \\
\hline Italy & 0.5 & 0.1 & 1.4 & 0.8 & 2.1 & 1.4 & -1.3 & -5.1 \\
\hline Luxembourg & 4.1 & 1.5 & 4.4 & 5.4 & 5.6 & 6.5 & 0.0 & -3.4 \\
\hline Spain & 2.7 & 3.1 & 3.3 & 3.6 & 4.0 & 3.6 & 0.9 & -3.6 \\
\hline United States & 1.8 & 2.5 & 3.6 & 3.1 & 2.7 & 2.1 & 0.4 & -2.4 \\
\hline \multicolumn{9}{|c|}{ B. Harmonised unemployment rates } \\
\hline & 2002 & 2003 & 2004 & 2005 & 2006 & 2007 & 2008 & 2009 \\
\hline Canada & 7.7 & 7.6 & 7.2 & 6.8 & 6.3 & 6.0 & 6.1 & 8.3 \\
\hline Germany & 8.4 & 9.3 & 9.8 & 10.6 & 9.8 & 8.4 & 7.3 & 7.5 \\
\hline Italy & 8.6 & 8.5 & 8.0 & 7.7 & 6.8 & 6.2 & 6.8 & 7.7 \\
\hline Luxembourg & 2.6 & 3.8 & 5.0 & 4.6 & 4.6 & 4.2 & 4.9 & 5.4 \\
\hline Spain & 11.1 & 11.1 & 10.6 & 9.2 & 8.5 & 8.3 & 11.4 & 18.0 \\
\hline United States & 5.8 & 6.0 & 5.5 & 5.1 & 4.6 & 4.6 & 5.8 & 9.3 \\
\hline \multicolumn{9}{|c|}{ Source: OECD (2010), Annex Tables 1 and 14} \\
\hline
\end{tabular}


Table 2: Portfolios participation rates for the whole population, 25 to 49 years olds and 50 and over.

\begin{tabular}{|c|c|c|c|c|c|c|c|}
\hline All & US & Canada & Germany & Italy & Luxembourg & Spain & Total \\
\hline Total Fin.Assets & 94.29 & 88.50 & 57.65 & 77.08 & 67.82 & 92.95 & 73.11 \\
\hline Deposit Accounts & 92.70 & 87.00 & na & 76.48 & na & 92.95 & 41.39 \\
\hline Risky Assets & 34.22 & 26.55 & na & 21.15 & na & 3.37 & 13.14 \\
\hline Main Residence & 71.86 & 65.47 & 41.15 & 70.25 & 71.03 & 83.10 & 55.57 \\
\hline Other Property & 19.99 & 16.75 & 13.21 & 22.02 & 27.84 & 36.43 & 17.17 \\
\hline Business Equity & 12.57 & 17.18 & 6.14 & 16.78 & 5.64 & 12.25 & 9.53 \\
\hline Total assets & 95.46 & 94.44 & 71.52 & 91.20 & 88.55 & 98.33 & 82.40 \\
\hline Total Debt & 77.34 & 69.86 & 36.55 & 25.79 & 35.14 & 46.28 & 50.10 \\
\hline Mortgage & 48.30 & 35.95 & 18.45 & 12.71 & 35.14 & 26.05 & 28.34 \\
\hline Other Home Debt & 5.80 & 4.71 & 5.88 & na & na & 8.02 & 5.50 \\
\hline Non-housing debt & 66.47 & 56.99 & 21.08 & 15.59 & na & 23.20 & 36.09 \\
\hline 24 to 49 year olds & US & Canada & Germany & Italy & Luxembourg & Spain & Total \\
\hline Total Fin.Assets & 91.97 & 86.17 & 52.32 & 79.73 & 64.40 & 92.05 & 70.97 \\
\hline Deposit Accounts & 90.25 & 84.64 & na & 79.23 & na & 92.05 & 43.77 \\
\hline Risky Assets & 32.55 & 24.85 & na & 16.50 & na & 2.48 & 13.30 \\
\hline Main Residence & 62.61 & 59.59 & 32.02 & 57.66 & 64.09 & 77.00 & 47.52 \\
\hline Other Property & 15.46 & 14.39 & 10.31 & 15.95 & 21.48 & 29.19 & 13.56 \\
\hline Business Equity & 12.87 & 18.91 & 7.36 & 21.41 & 5.60 & 14.94 & 10.95 \\
\hline Total assets & 93.53 & 93.17 & 64.97 & 88.62 & 86.58 & 98.08 & 79.06 \\
\hline Total Debt & 86.56 & 81.86 & 50.36 & 40.64 & 53.91 & 66.61 & 64.34 \\
\hline Mortgage & 55.46 & 46.48 & 24.93 & 22.76 & 53.91 & 45.41 & 37.28 \\
\hline Other Home Debt & 6.21 & 4.98 & 5.62 & na & na & 10.05 & 5.67 \\
\hline Non-housing debt & 77.31 & 68.07 & 31.22 & 22.59 & na & 30.23 & 47.91 \\
\hline 50 and over & US & Canada & Germany & Italy & Luxembourg & Spain & Total \\
\hline Total Fin.Assets & 96.56 & 91.37 & 61.51 & 75.37 & 71.85 & 93.76 & 74.85 \\
\hline Deposit Accounts & 95.09 & 89.91 & na & 74.71 & na & 93.76 & 39.45 \\
\hline Risky Assets & 35.86 & 28.65 & na & 24.15 & na & 4.17 & 13.01 \\
\hline Main Residence & 80.93 & 72.71 & 47.78 & 78.38 & 78.40 & 88.53 & 62.13 \\
\hline Other Property & 24.43 & 19.66 & 15.31 & 25.94 & 34.97 & 42.89 & 20.12 \\
\hline Business Equity & 12.27 & 15.06 & 5.25 & 13.80 & 5.67 & 9.85 & 8.37 \\
\hline Total assets & 97.36 & 96.00 & 76.28 & 92.87 & 90.70 & 98.56 & 85.12 \\
\hline Total Debt & 68.31 & 55.08 & 26.53 & 16.21 & 14.95 & 28.14 & 38.50 \\
\hline Mortgage & 41.29 & 22.98 & 13.74 & 6.22 & 14.95 & 8.78 & 21.05 \\
\hline Other Home Debt & 5.40 & 4.38 & 6.07 & na & na & 6.20 & 5.37 \\
\hline Non-housing debt & 55.84 & 43.35 & 13.72 & 11.08 & na & 16.92 & 26.46 \\
\hline
\end{tabular}

Source: 2005 SFS, 2007 SCF, 2007 SOEP, 2008 SHIW, 2007 PSELL3 and 2008 EFF 
Table 3: Mean level of each instrument in the wealth portfolio for the whole population, 25 to 49 years olds and 50 and over by country.

\begin{tabular}{|c|c|c|c|c|c|c|c|}
\hline & US & Canada & Germany & Italy & Luxembourg & Spain & Total \\
\hline Total Fin.Assets & 176,020 & 16,835 & 22,243 & 22,064 & 33,446 & 22,235 & 69,758 \\
\hline Deposit Accounts & 19,510 & 7,607 & na & 11,846 & na & 19,480 & 8,043 \\
\hline Risky Assets & 51,013 & 8,191 & na & 9,318 & na & 1,871 & 16,828 \\
\hline Main Residence & 206,655 & 68,364 & 101,139 & 188,389 & 381,255 & 227,195 & 145,330 \\
\hline Other Property & 56,090 & 11,790 & 27,318 & 38,578 & 126,962 & 94,656 & 39,910 \\
\hline Business Equity & 57,570 & 5,098 & 8,952 & 22,471 & 17,917 & 30,282 & 25,844 \\
\hline Total assets & 544,560 & 109,413 & 168,087 & 281,325 & 570,226 & 380,630 & 301,575 \\
\hline Total Debt & 96,811 & 26,838 & 31,016 & 10,381 & 48,678 & 36,704 & 50,190 \\
\hline Mortgage & 69,184 & 17,620 & 17,899 & 9,157 & 48,678 & 24,048 & 32,952 \\
\hline Other Home Debt & 7,649 & 2,176 & 6,924 & na & na & 8,434 & 6,566 \\
\hline Non-housing debt & 13,732 & 4,090 & 3,920 & 1,131 & na & 3,197 & 6,736 \\
\hline 24 to 49 year olds & US & Canada & Germany & Italy & Luxembourg & Spain & Total \\
\hline Total Fin.Assets & 92,840 & 8,843 & 13,081 & 15,073 & 24,520 & 15,902 & 40,455 \\
\hline Deposit Accounts & 13,334 & 3,747 & na & 9,632 & na & 14,627 & 6,018 \\
\hline Risky Assets & 22,800 & 4,978 & na & 5,081 & na & 1,010 & 8,360 \\
\hline Main Residence & 173,637 & 62,973 & 77,606 & 153,986 & 327,936 & 208,027 & 121,570 \\
\hline Other Property & 35,830 & 10,180 & 17,228 & 21,679 & 72,421 & 66,483 & 26,163 \\
\hline Business Equity & 43,288 & 4,953 & 9,547 & 26,321 & 18,473 & 30,233 & 22,932 \\
\hline Total assets & 367,063 & 92,916 & 124,171 & 223,285 & 453,052 & 323,897 & 222,651 \\
\hline Total Debt & 115,656 & 35,635 & 43,456 & 19,449 & 80,536 & 60,007 & 67,313 \\
\hline Mortgage & 85,549 & 24,778 & 29,174 & na & 80,536 & 43,400 & 47,390 \\
\hline Other Home Debt & 7,552 & 2,405 & 6,056 & na & na & 11,079 & 6,283 \\
\hline Non-housing debt & 17,353 & 5,101 & 5,577 & 1,701 & na & 3,954 & 9,255 \\
\hline 50 and over & US & Canada & Germany & Italy & Luxembourg & Spain & Total \\
\hline Total Fin.Assets & 257,549 & 26,678 & 28,895 & 26,576 & 43,125 & 27,884 & 93,642 \\
\hline Deposit Accounts & 25,564 & 12,361 & na & 13,276 & na & 23,808 & 9,695 \\
\hline Risky Assets & 78,667 & 12,149 & na & 12,054 & na & 2,639 & 23,730 \\
\hline Main Residence & 239,019 & 75,003 & 118,227 & 210,596 & 439,071 & 244,294 & 164,697 \\
\hline Other Property & 75,950 & 13,772 & 34,646 & 49,488 & 186,102 & 119,787 & 51,115 \\
\hline Business Equity & 71,568 & 5,277 & 8,520 & 19,985 & 17,314 & 30,325 & 28,218 \\
\hline Total assets & 718,537 & 129,732 & 199,975 & 318,791 & 697,280 & 431,238 & 365,904 \\
\hline Total Debt & 78,339 & 16,003 & 21,983 & 4,527 & 14,133 & 15,918 & 36,233 \\
\hline Mortgage & 53,144 & 8,804 & 9,712 & na & 14,133 & 6,786 & 21,183 \\
\hline Other Home Debt & 7,744 & 1,894 & 7,555 & na & na & 6,075 & 6,798 \\
\hline Non-housing debt & 10,184 & 2,844 & 2,718 & 762 & na & 2,521 & 4,682 \\
\hline
\end{tabular}

Source: 2005 SFS, 2007 SCF, 2007 SOEP, 2008 SHIW, 2007 PSELL3 and 2008 EFF Note: The levels are in 2007 Euros and include zeros. 
Table 4: Mean level of each instrument in the wealth portfolio as a proportion of total assets for the whole population, 25 to 49 years olds and 50 and over by country.

US Canada Germany Italy Luxembourg Spain Total

\begin{tabular}{lccccccc}
\hline Total Fin.Assets & 35 & 16 & 14 & 8 & 6 & 6 & 25 \\
Deposit Accounts & 4 & 7 & na & 4 & na & 5 & 3 \\
Risky Assets & 10 & 8 & na & 3 & na & 0 & 6 \\
Main Residence & 42 & 67 & 63 & 69 & 68 & 61 & 52 \\
Other Property & 11 & 12 & 17 & 14 & 23 & 25 & 14 \\
Business Equity & 12 & 5 & 6 & 8 & 3 & 8 & 9 \\
Total Assets & 100 & 100 & 100 & 100 & 100 & 100 & 100 \\
Total Debt & 20 & 26 & 19 & 4 & 9 & 10 & 18 \\
Mortgage & 14 & 17 & 11 & 3 & 9 & 6 & 12 \\
Other Home Debt & 2 & 2 & 4 & na & na & 2 & 2 \\
Non-housing Debt & 3 & 4 & 2 & 0 & na & 1 & 2 \\
\hline \hline
\end{tabular}

24 to 49 year olds US Canada Germany Italy Luxembourg Spain Total

\begin{tabular}{lccccccc}
\hline Total Fin.Assets & 27 & 10 & 11 & 7 & 6 & 5 & 19 \\
Deposit Accounts & 4 & 4 & na & 4 & na & 5 & 3 \\
Risky Assets & 7 & 6 & na & 2 & na & 0 & 4 \\
Main Residence & 50 & 72 & 66 & 71 & 74 & 65 & 58 \\
Other Property & 10 & 12 & 15 & 10 & 16 & 21 & 12 \\
Business Equity & 13 & 6 & 8 & 12 & 4 & 9 & 11 \\
Total Assets & 100 & 100 & 100 & 100 & 100 & 100 & 100 \\
Total Debt & 33 & 41 & 37 & 9 & 18 & 19 & 32 \\
Mortgage & 25 & 28 & 25 & 8 & 18 & 14 & 23 \\
Other Home Debt & 2 & 3 & 5 & na & na & 3 & 3 \\
Non-housing Debt & 5 & 6 & 5 & 1 & na & 1 & 4 \\
\hline \hline
\end{tabular}

50 and over US Canada Germany Italy Luxembourg Spain Total

\begin{tabular}{lccccccc}
\hline Total Fin.Assets & 40 & 22 & 15 & 9 & 6 & 7 & 28 \\
Deposit Accounts & 4 & 10 & 0 & 4 & 0 & 6 & 3 \\
Risky Assets & 12 & 10 & 0 & 4 & 0 & 1 & 7 \\
Main Residence & 37 & 62 & 62 & 69 & 64 & 58 & 49 \\
Other Property & 12 & 11 & 18 & 16 & 27 & 28 & 15 \\
Business Equity & 11 & 4 & 4 & 7 & 3 & 7 & 8 \\
Total Assets & 100 & 100 & 100 & 100 & 100 & 100 & 100 \\
Total Debt & 12 & 13 & 12 & 1 & 2 & 4 & 11 \\
Mortgage & 8 & 7 & 5 & 1 & 2 & 2 & 6 \\
Other Home Debt & 1 & 2 & 4 & na & na & 1 & 2 \\
Non-housing Debt & 2 & 2 & 1 & 0 & na & 1 & 1 \\
\hline \hline
\end{tabular}

Source: 2005 SFS, 2007 SCF, 2007 SOEP, 2008 SHIW, 2007 PSELL3 and 2008 EFF Note: The levels are in 2007 Euros and include zeros. 
Table 5: Institutional Indices.

\begin{tabular}{|c|c|c|c|}
\hline Index & Description & Scale & Source \\
\hline Financial development & $\begin{array}{l}\text { Measures the beadth, depth and efficiency of financial systems } \\
\text { and capital markets }\end{array}$ & $\begin{array}{l}1-7 \text { with higher values } \\
\text { indicating more development }\end{array}$ & Financial development report 2008 \\
\hline Economic freedom & Measures the level of government interference in the economy & $\begin{array}{l}0-100 \text { with higher values } \\
\text { indicating more freedom }\end{array}$ & 2007 Index of Economic Freedom \\
\hline Bank regulation & $\begin{array}{l}\text { Measures anticompetitive regulations in banking taking into } \\
\text { account regulatory barriers on domestic and foreign entry, restrictions } \\
\text { on banking activities and the extent of government ownership }\end{array}$ & $\begin{array}{l}0-5 \text { with higher values } \\
\text { indicating more regulation }\end{array}$ & Andrews et al, 2011 \\
\hline Marginal Tax Rate & $\begin{array}{l}\text { Net personal marginal tax rate of a single person } \\
\text { earning } 67 \% \text { or } 167 \% \text { of the average wage in } 2007\end{array}$ & $\%$ & OECD Stat \\
\hline Hh equity in pensions & $\begin{array}{l}\text { Net equity of households in life insurance } \\
\text { and pension funds reserves in } 2007\end{array}$ & Euro/capita & OECD Stat \\
\hline Tax/GDP & $\begin{array}{l}2007 \text { taxes on income, wealth, etc. } \\
\text { as a percentage of GDP }\end{array}$ & $\%$ & OECD Stat \\
\hline Capital tax/GDP & 2007 capital taxes as a percentage of GDP & $\%$ & OECD Stat \\
\hline Tax on Dividends & $\begin{array}{l}\text { Net top statutory rate to be paid at the shareholder } \\
\text { level in } 2007\end{array}$ & $\%$ & OECD Stat \\
\hline Mortgage Maturity & Typical mortgage maturity term & years & Andrews et al, 2011 \\
\hline Fixed rate mortgages & $\begin{array}{l}\text { Prevailing type of interest rate. Measured as the proprtion } \\
\text { of fixed rate mortgages. }\end{array}$ & $\%$ & Andrews et al, 2011 \\
\hline Max. LTV ratio & Regulatory limit on mortgage loan to value limits & $\%$ & Andrews et al, 2011 \\
\hline Mathematical literacy & Measures the mathematical skills of 15 year olds & $\begin{array}{l}\text { The average score among OECD } \\
\text { countries is } 500 \text { points and the } \\
\text { standard deviation is } 100 \text { points. }\end{array}$ & PISA 2006 \\
\hline
\end{tabular}

Table 6: Coefficients from a bivariate regression of the unexplained wealth gap on institutional indices.

\begin{tabular}{|c|c|c|c|c|c|c|c|c|c|c|}
\hline & TFA u-50 & TFA o-50 & PR u-50 & PR o-50 & IR u-50 & IR o-50 & MG u-50 & MG o-50 & NHD u-50 & NHD o-50 \\
\hline Financial Development & $-1.72 * *$ & $-2.24 *$ & -1.46 & -2.57 & -0.50 & -0.15 & $-0.09 * * *$ & $-0.22 * *$ & -0.02 & 0.04 \\
\hline Economic Freedom & $-0.15^{* *}$ & $-0.15^{*}$ & -0.09 & -0.15 & -0.06 & -0.02 & $-0.01 * * *$ & $-0.02 * *$ & -0.00 & 0.00 \\
\hline Bank Regulation & -0.33 & -0.81 & -0.81 & -1.67 & 0.58 & 0.48 & 0.03 & -0.02 & -0.07 & -0.03 \\
\hline Mortgage Maturity & -0.16 & $-0.22 * *$ & -0.14 & $-0.26^{*}$ & -0.03 & -0.01 & $-0.01 * *$ & $-0.02 *$ & -0.00 & 0.00 \\
\hline Prop. Of fixed rate mortgages & -0.00 & -0.02 & -0.01 & $-0.03^{* *}$ & 0.01 & 0.01 & -0.00 & -0.00 & 0.00 & $0.00 *$ \\
\hline Max. LTV & -0.04 & -0.02 & -0.01 & -0.01 & -0.03 & -0.01 & -0.00 & -0.01 & $-0.00 * *$ & -0.00 \\
\hline Math Literacy & -0.01 & -0.02 & -0.01 & -0.03 & 0.01 & 0.01 & -0.00 & -0.00 & 0.00 & 0.00 \\
\hline Marg. Tax rate (low earner) & 0.00 & -0.01 & -0.02 & 0.00 & $0.07 *$ & $0.04 * * *$ & 0.00 & 0.00 & $0.01 *$ & 0.00 \\
\hline Marg. Tax rate (high earner) & -0.05 & -0.05 & -0.05 & -0.02 & -0.04 & -0.00 & 0.00 & -0.00 & 0.00 & -0.00 \\
\hline Hh equity in pensions & $-0.02 *$ & -0.01 & -0.01 & 0.00 & $-0.02 * * *$ & $-0.01 *$ & -0.00 & $-0.00 *$ & -0.00 & -0.00 \\
\hline Tax/GDP & 0.13 & 0.04 & 0.02 & -0.09 & $0.13^{* *}$ & 0.05 & 0.00 & 0.01 & -0.02 & -0.01 \\
\hline Capital tax/GDP & 2.50 & 3.51 & 3.24 & 3.68 & 0.49 & -0.55 & -0.03 & 0.12 & -0.03 & -0.00 \\
\hline Tax on dividends & -0.11 & -0.18 & -0.10 & -0.25 & 0.04 & 0.03 & $-0.01 *$ & -0.01 & 0.00 & $0.01 *$ \\
\hline
\end{tabular}


Figure 1 Level of each wealth component (excluding zeros) across the income distribution for the 25 to 49 population (top) and 50 and over (bottom).
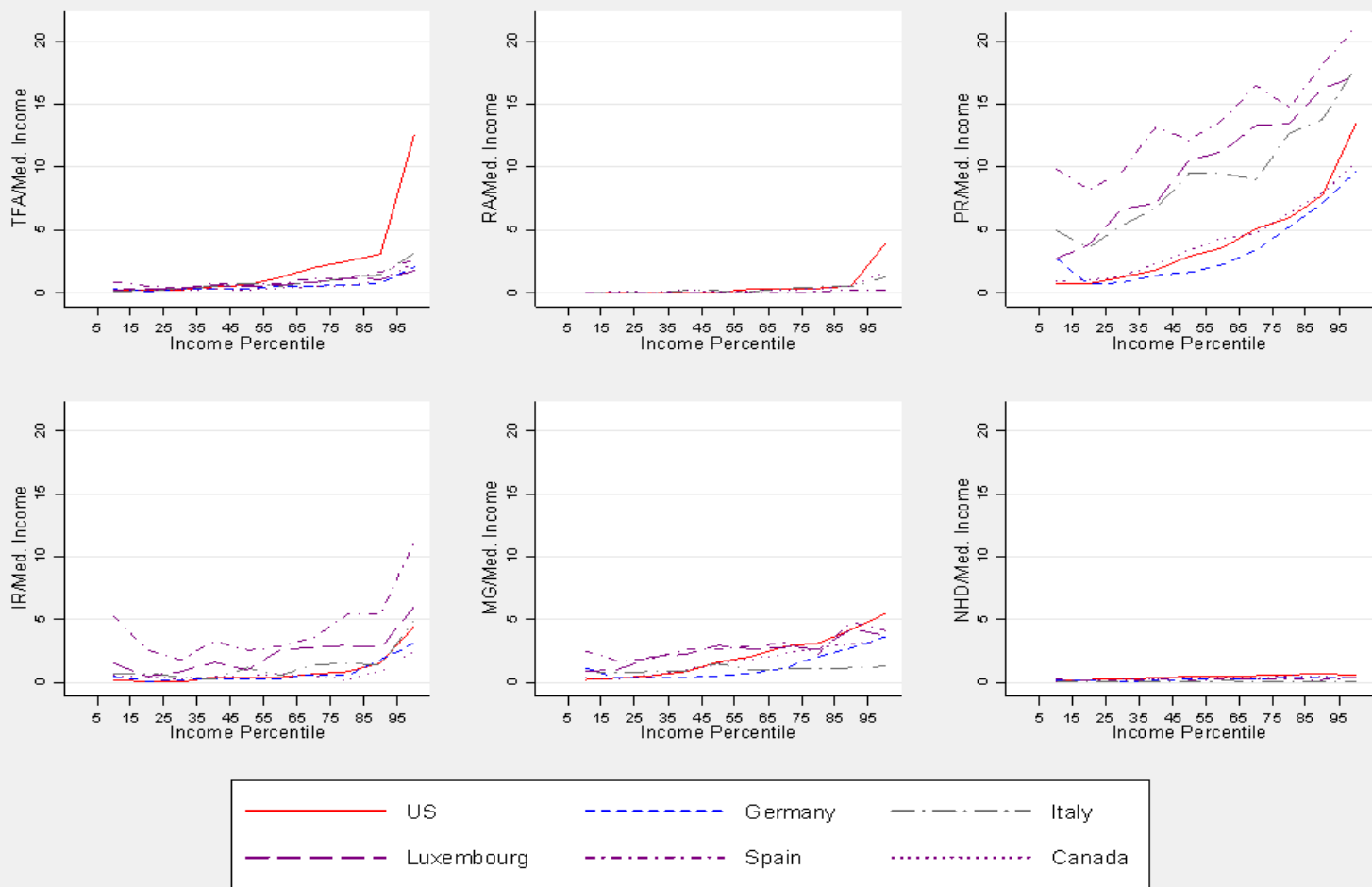

Participation across the income distribution for 50 and over (below)
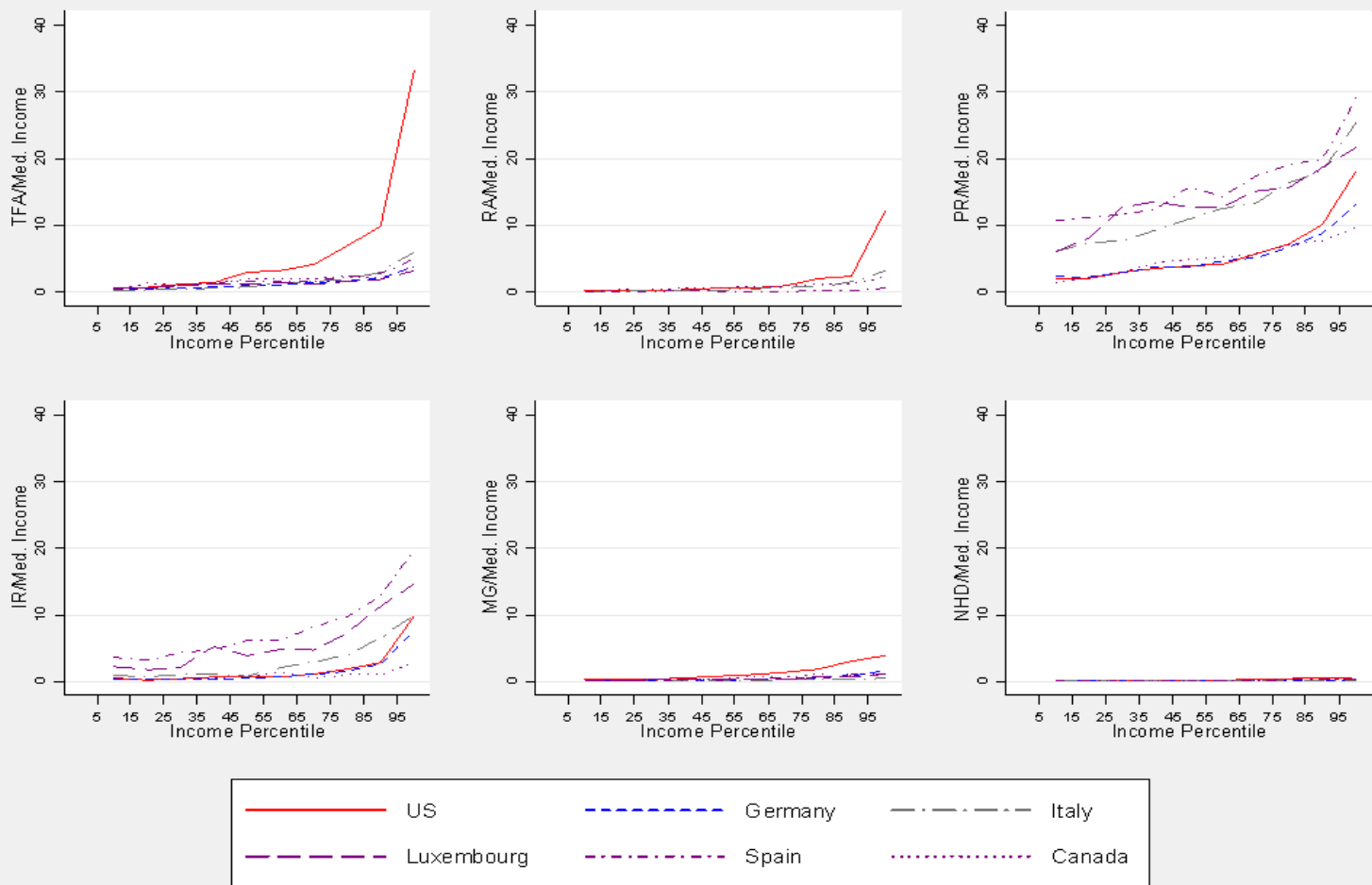

Source: 2005 SFS, 2007 SCF, 2007 SOEP, 2008 SHIW, 2007 PSELL3 and 2008 EFF Note: Weighted statistics. Lowess curve applied for smoothing purposes. TFA is Total Financial Assets, RA is Risky Assets, PR iszRrincipal Residence, IR is Investment Real Estate, MG is Mortgage and NHD is Non-housing debt. 
Figure 2 Predicted levels of assets/liabilities in the Total Asset portfolio for the $\mathrm{u}-50$ population
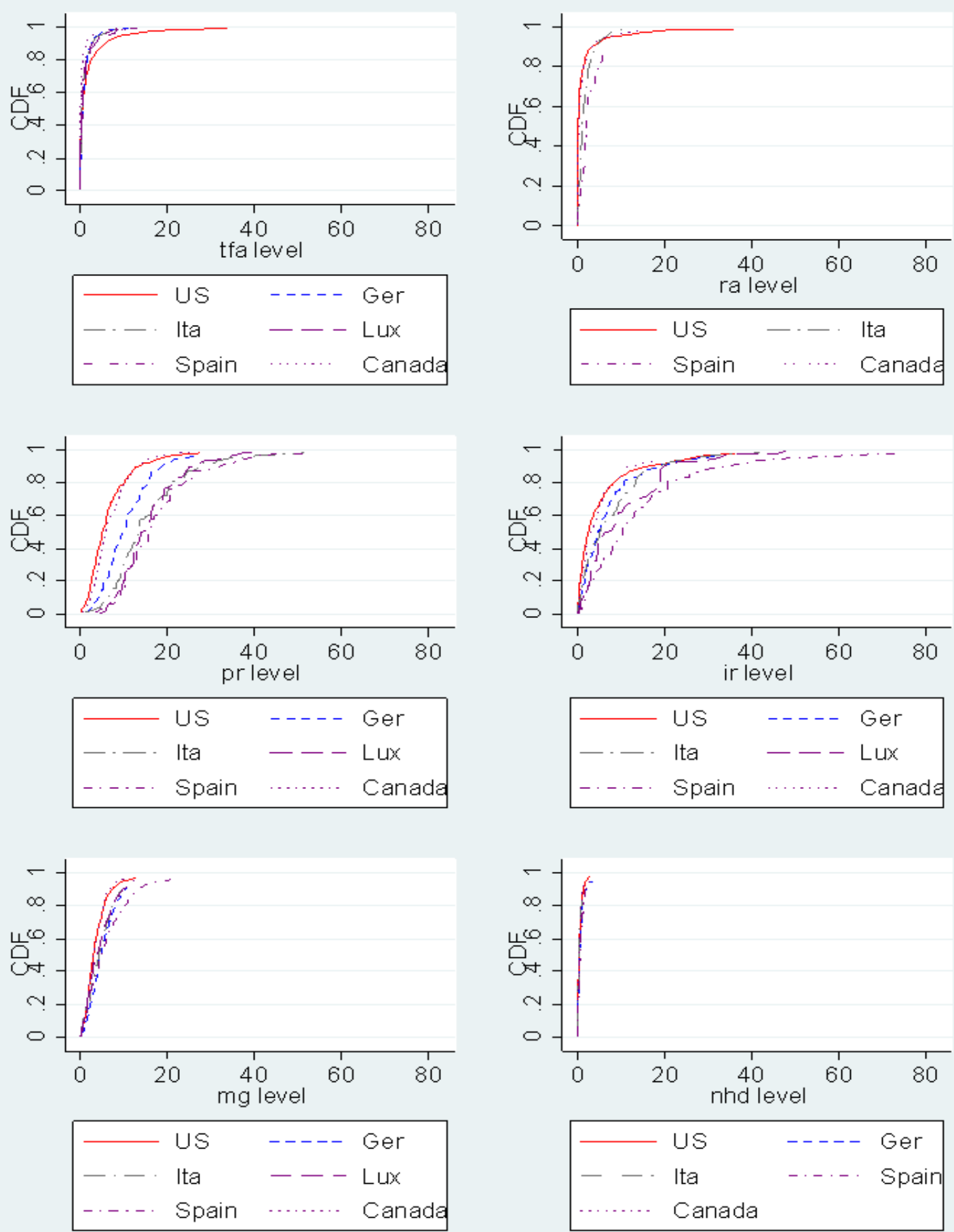

Source: 2007 SCF, 2005 SFS, 2007 SOEP, 2008 SHIW, 2007 PSELL3 and 2008 EFF Note: Asset levels are scaled by the median income. TFA is Total Financial Assets, RA is Risky Assets, PR is Principal Residence, IR is Investment Real Estate, MG is Mortgage and NHD is Non-housing debt. 
Figure 3 Example: Decomposition of the principal residence gap across the distribution of principal residence for the $\mathrm{u}-50$ households

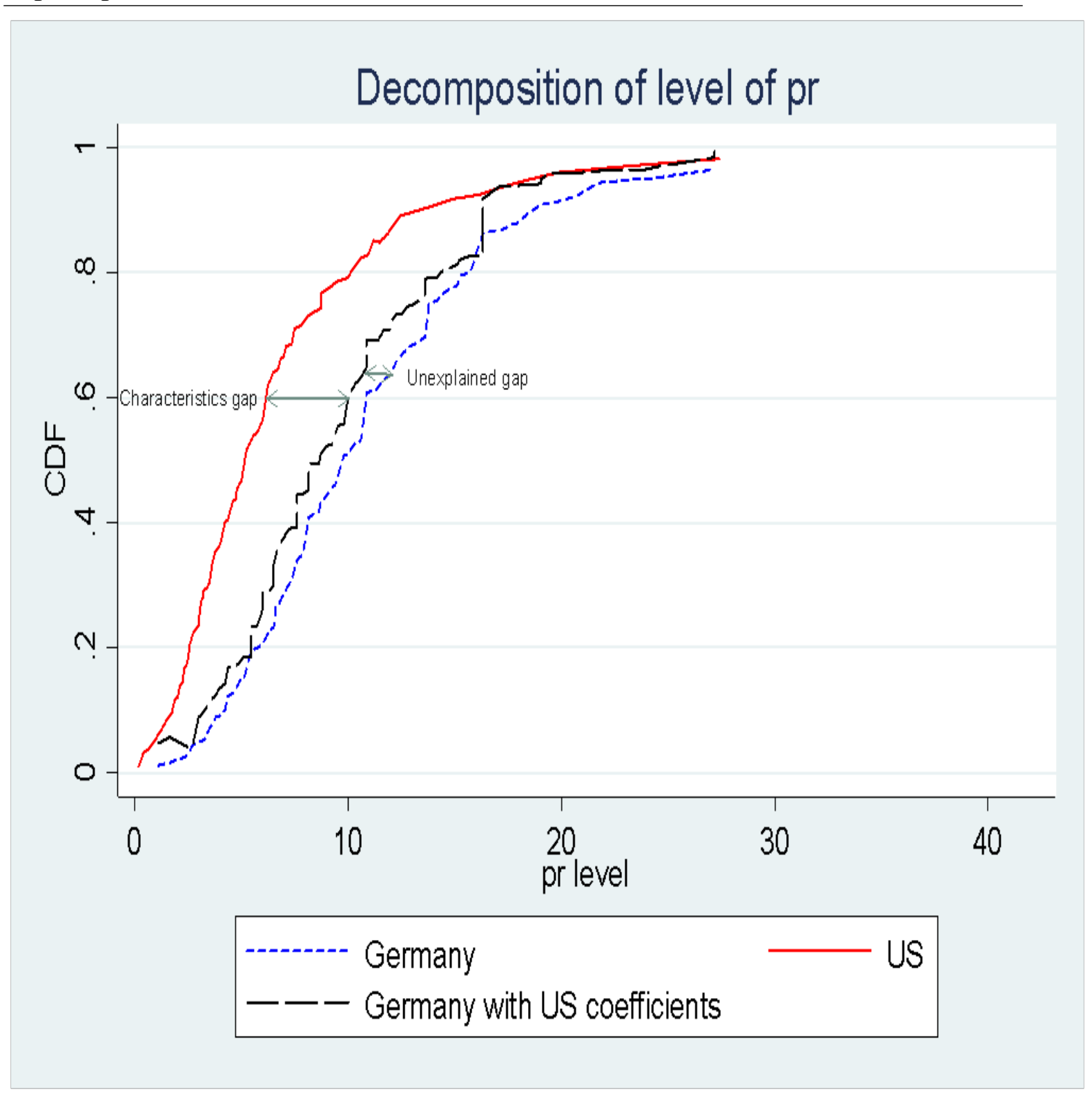

Source: 2007 SOEP

Note: Principal residence levels are scaled by the median income. 
$\overline{\text { Figure } 4 \text { Coefficient and institutional gaps across the distribution of total financial assets. }}$
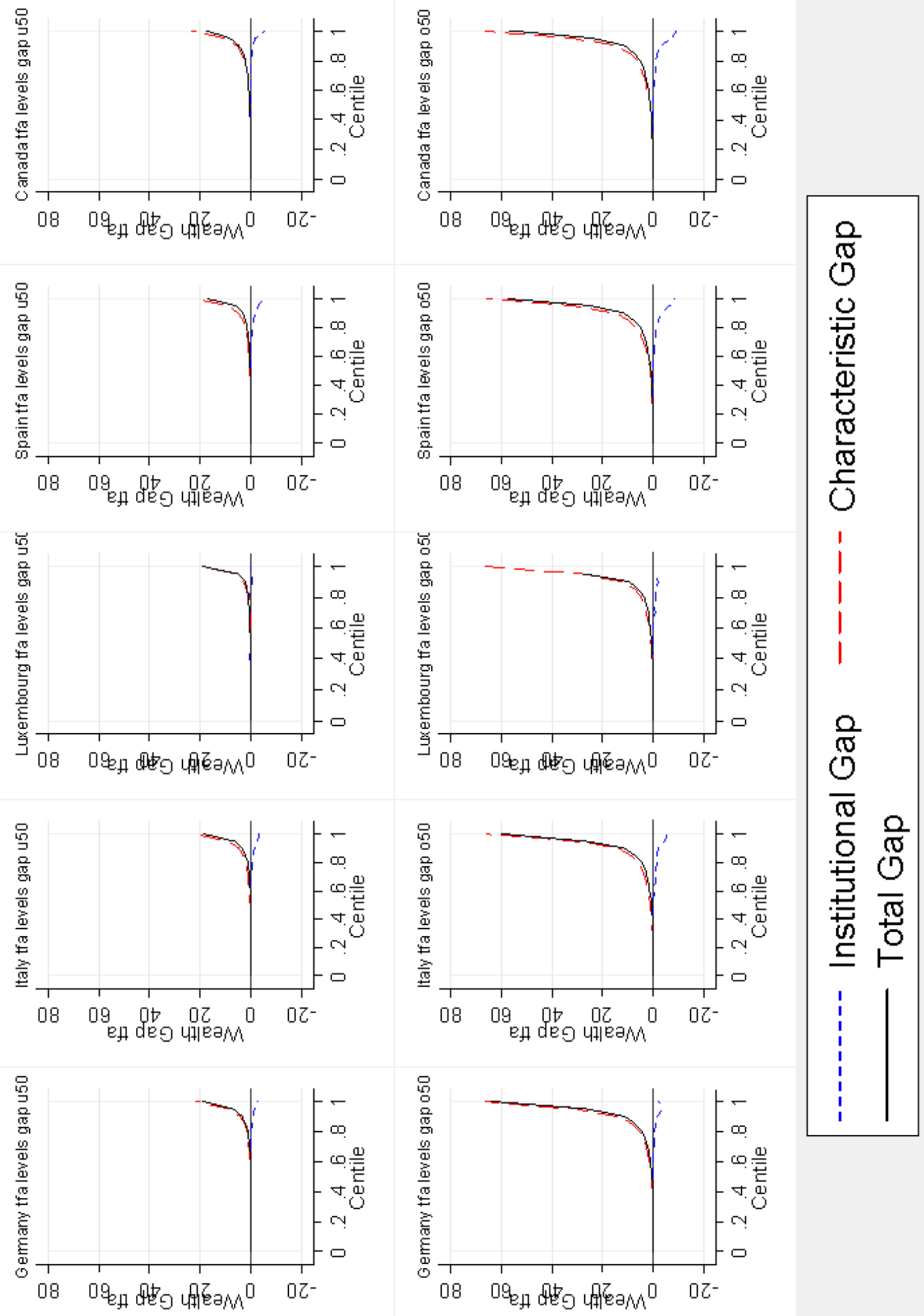

Source: 2007 SCF, 2005 SFS, 2007 SOEP, 2008 SHIW, 2007 PSELL3 and 2008 EFF Note: The wealth gaps are scaled by the median income. The characteristics gap shows the level of difference between the US and each country's investment in total financial assets which is accounted for by household characteristics. The institutional gap shows the gap which is unexplained. The total gap 3 is the sum of these two. 

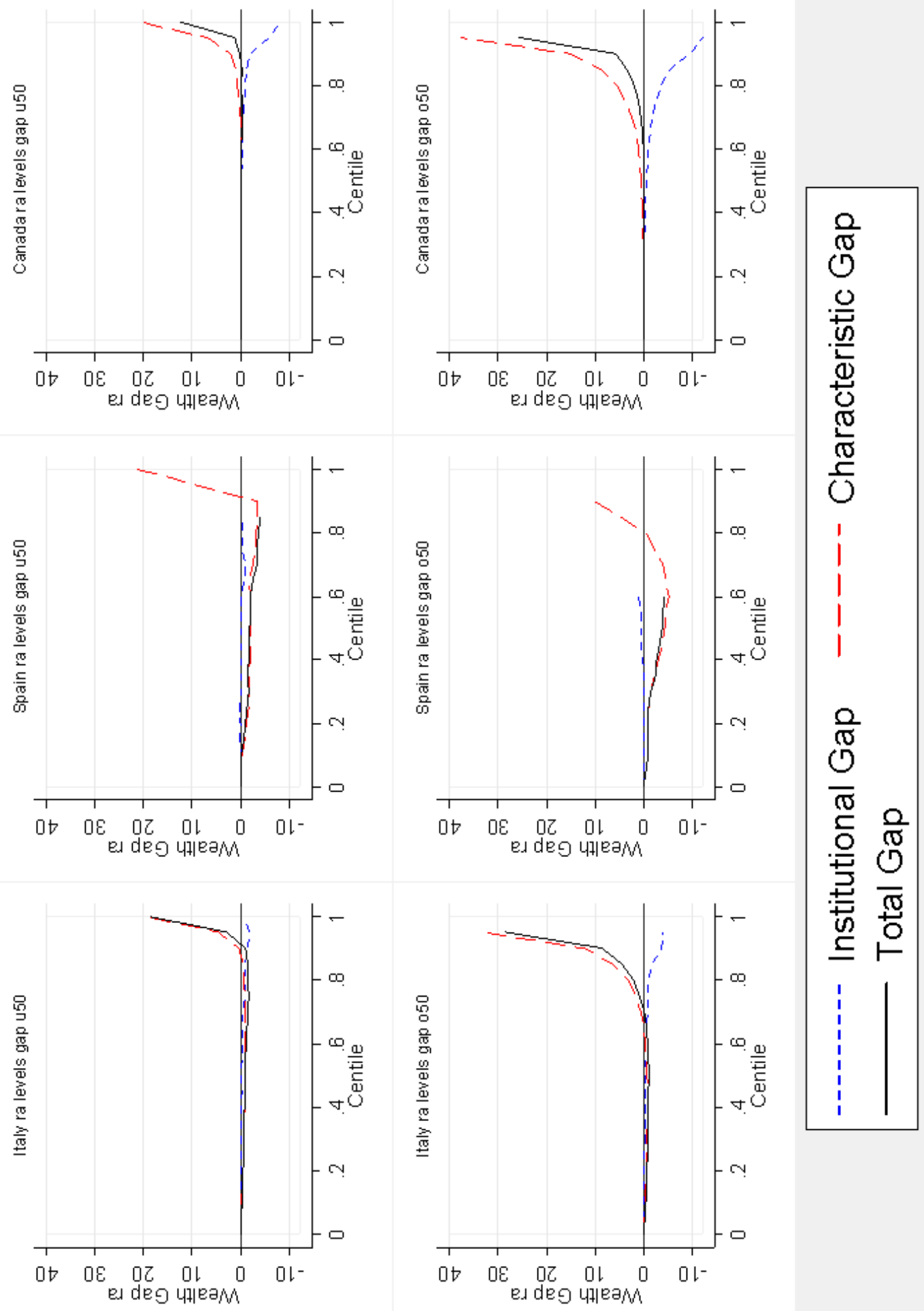

Source: 2007 SCF, 2005 SFS, 2007 SOEP, 2008 SHIW, 2007 PSELL3 and 2008 EFF Note:The wealth gaps are scaled by the median income. The characteristics gap shows the level of difference between the US and each country's investment in risky assets which is accounted for by household characteristics. The institutional gap shows the gap which is unexplained. The total gap is the suzn of these two. 

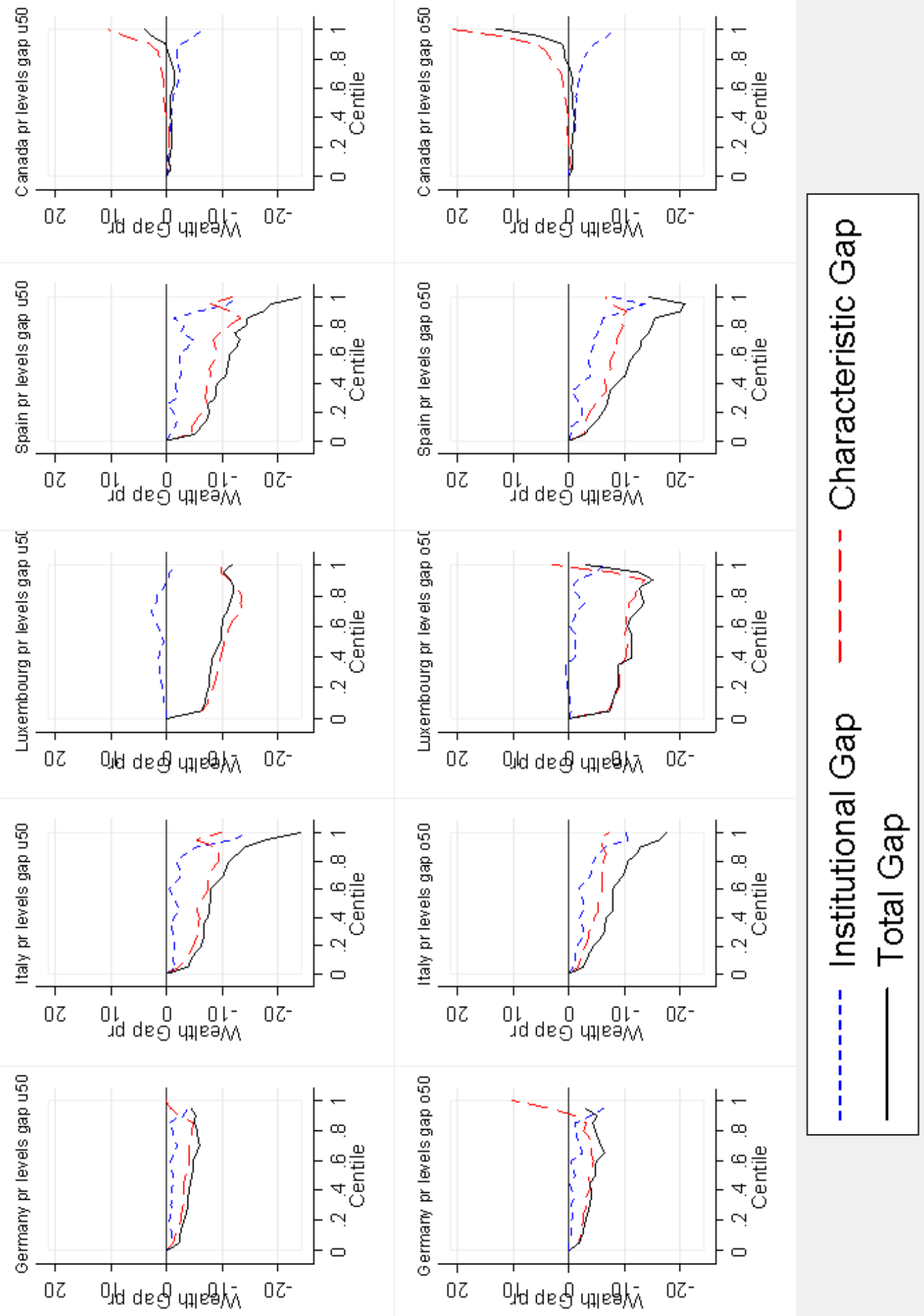

Source: 2007 SCF, 2005 SFS, 2007 SOEP, 2008 SHIW, 2007 PSELL3 and 2008 EFF Note:The wealth gaps are scaled by the median income. The characteristics gap shows the level of difference between the US and each country's investment in principal residence which is accounted for by household characteristics. The institutional gap shows the gap which is unexplained. The tợal gap is the sum of these two. 
Figure 7 Coefficient and institutional gaps across the distribution of Investment Real Es$\underline{\text { tate }}$
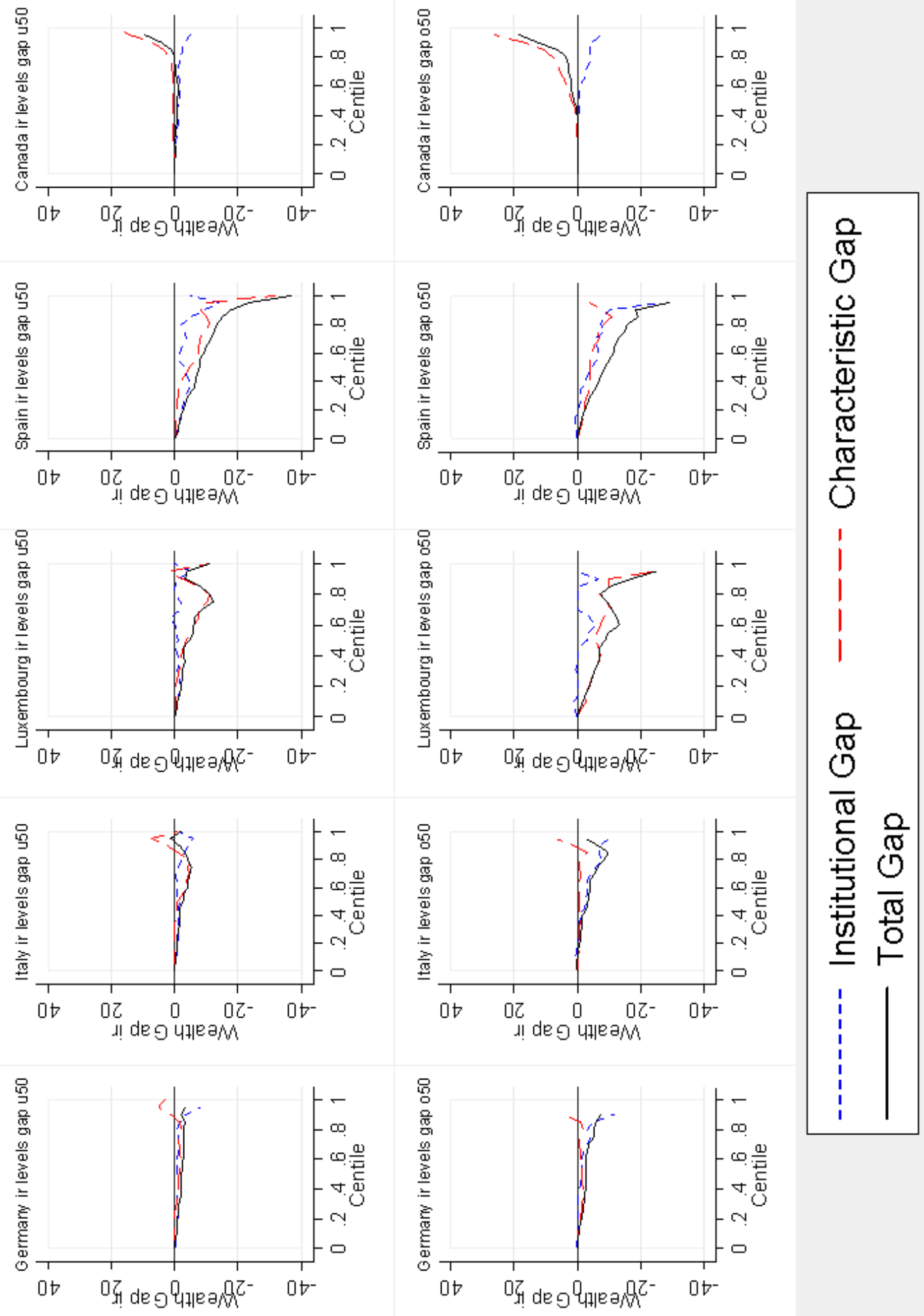

Source: 2007 SCF, 2005 SFS, 2007 SOEP, 2008 SHIW, 2007 PSELL3 and 2008 EFF Note:The wealth gaps are scaled by the median income. The characteristics gap shows the level of difference between the US and each country's investment in investment real estate which is accounted for by household characteristics. The institutional gap shows the gap which is unexplained. The total gap is the sum of these two. 

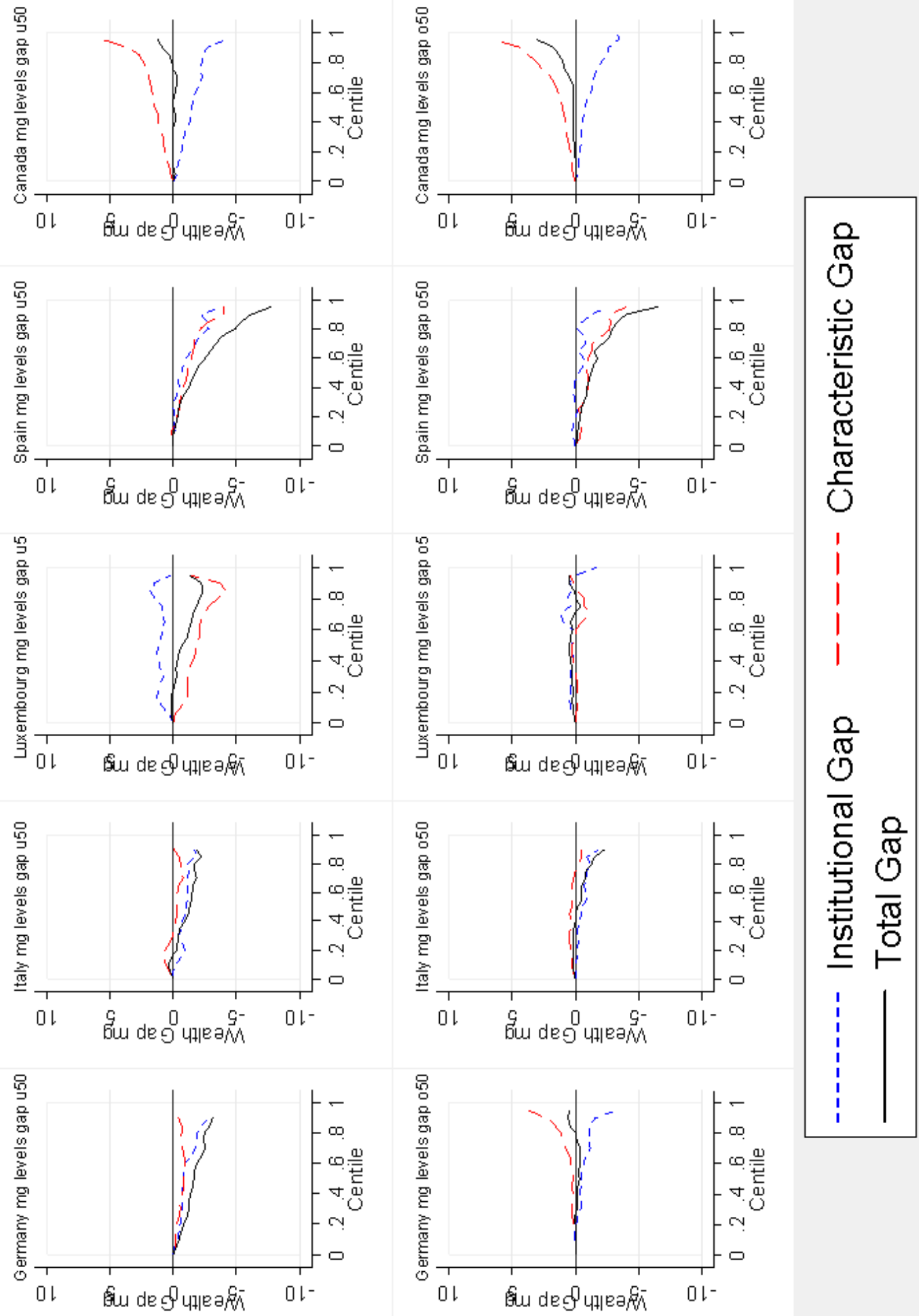

Source: 2007 SCF, 2005 SFS, 2007 SOEP, 2008 SHIW, 2007 PSELL3 and 2008 EFF Note: The wealth gaps are scaled by the median income. The characteristics gap shows the level of difference between the US and each country's investment in mortgage debt which is accounted for by household characteristics. The institutional gap shows the gap which is unexplained. The total gap is the sum of these two. 

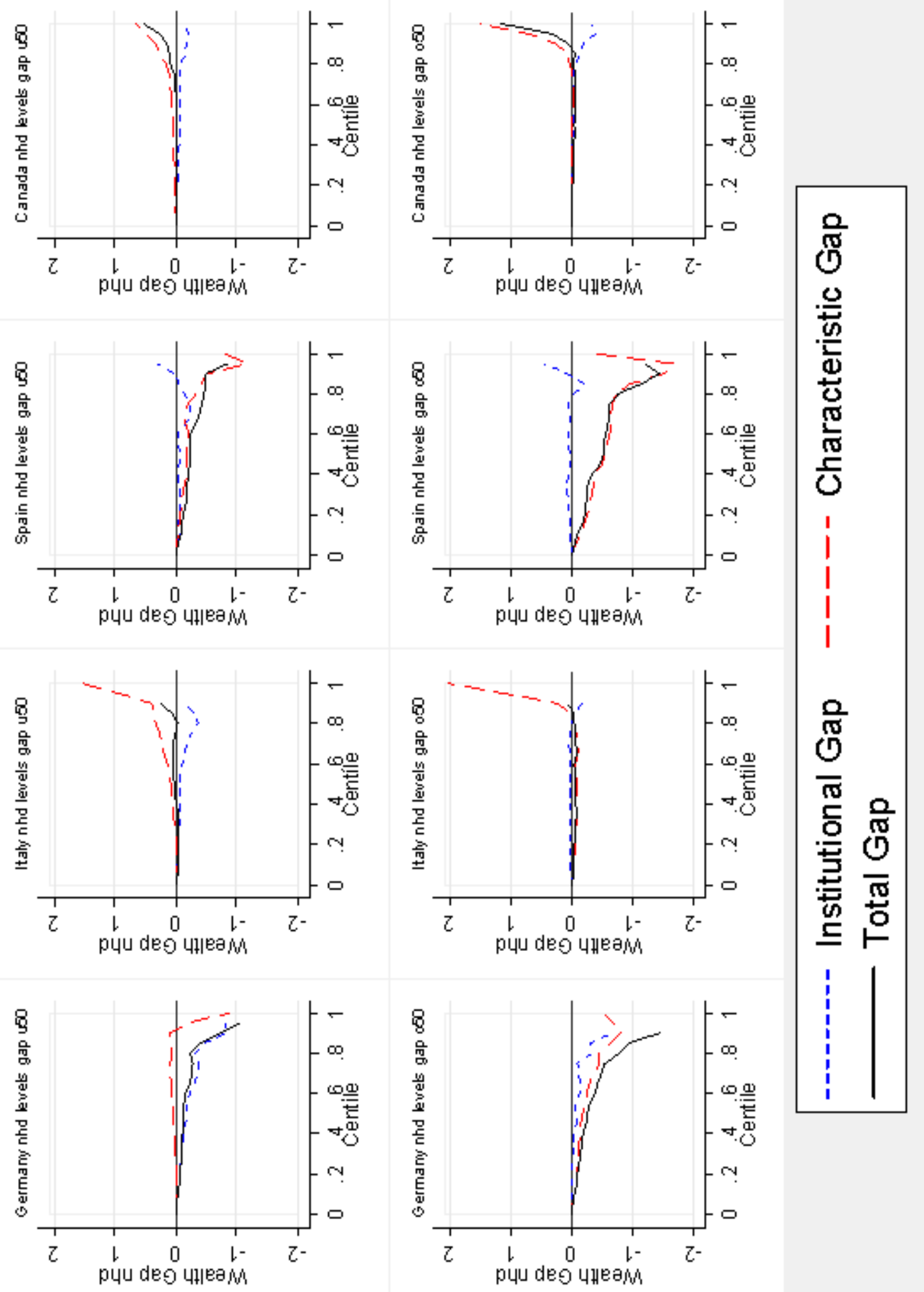

Source: 2007 SCF, 2005 SFS, 2007 SOEP, 2008 SHIW, 2007 PSELL3 and 2008 EFF Note: The wealth gaps are scaled by the median income. The characteristics gap shows the level of difference between the US and each country's investment in non-housing debt which is accounted for by household characteristics. The institutional gap shows the gap which is unexplained. The total gap is the sum of these two. 


\section{Appendix}

Table A.1: Overview of wealth portfolio components across the sample surveys.

\begin{tabular}{|c|c|c|c|c|c|c|c|}
\hline Components & & US & Canada & Germany & Italy & Luxembourg & Spain \\
\hline \multirow[t]{3}{*}{ Financial Assets } & & sum & sum & $\mathrm{X}$ & sum & collected in brackets & sum \\
\hline & Deposit accounts & $\mathrm{X}$ & $\mathrm{X}$ & not included & $X$ & na & $\mathrm{X}$ \\
\hline & Risky assets & $X$ & $\mathrm{X}$ & na & $X$ & na & $\mathrm{X}$ \\
\hline \multirow{2}{*}{\multicolumn{2}{|c|}{$\begin{array}{l}\text { Principle residence: current value of own home } \\
\text { Investment real estate }\end{array}$}} & $X$ & $\mathrm{X}$ & $X$ & $X$ & $\mathrm{X}$ & $X$ \\
\hline & & $X$ & $\mathrm{X}$ & $\mathrm{X}$ & $\mathrm{X}$ & net of mortgages & $\mathrm{X}$ \\
\hline \multicolumn{2}{|c|}{ Business Equity } & $\mathrm{X}$ & $\mathrm{X}$ & $\mathrm{X}$ & $\mathrm{X}$ & $\mathrm{X}$ & $\mathrm{X}$ \\
\hline \multicolumn{2}{|l|}{ Total Debt } & sum & sum & sum & sum & sum & sum \\
\hline \multirow[t]{3}{*}{ Total Mortgage } & & sum & sum & sum & $\mathrm{X}$ & na & sum \\
\hline & Mortgages (main home) & $\mathrm{X}$ & $\mathrm{X}$ & $\mathrm{X}$ & na & $\mathrm{X}$ & $X$ \\
\hline & Other mortgages & $X$ & $\mathrm{X}$ & $\mathrm{X}$ & na & na & $X$ \\
\hline Non-housing debt & & $X$ & $\mathrm{X}$ & $\mathrm{X}$ & $\mathrm{X}$ & na & $\mathrm{X}$ \\
\hline
\end{tabular}

Source: 2005 SFS, 2007 SCF, 2007 SOEP, 2008 SHIW, 2007 PSELL3 and 2008 EFF 
Table A.2: Descriptive statistics (means) by country and age groups.

\begin{tabular}{|c|c|c|c|c|c|c|c|}
\hline 25 to 49 year olds & US & Canada & Germany & Italy & Luxembourg & Spain & Total \\
\hline age & 38.04 & 37.37 & 38.70 & 39.63 & 38.75 & 38.74 & 38.48 \\
\hline male $(0 / 1)$ & 0.78 & 0.61 & 0.52 & 0.66 & 0.45 & 0.50 & 0.62 \\
\hline no. of children lt 18 & 1.34 & 0.42 & 0.79 & 0.94 & 1.00 & 0.93 & 0.98 \\
\hline $\mathrm{s} * 100$ & 20.59 & 33.42 & 36.51 & 27.50 & 24.08 & 19.21 & 29.41 \\
\hline $\mathrm{sp} * 100$ & 15.18 & 7.92 & 11.02 & 6.47 & 6.52 & 9.59 & 11.96 \\
\hline $\mathrm{cp} * 100$ & 15.74 & 22.11 & 16.53 & 16.26 & 15.06 & 11.32 & 16.15 \\
\hline $\mathrm{cpk} * 100$ & 48.49 & 36.55 & 35.94 & 49.78 & 54.34 & 59.88 & 42.28 \\
\hline married & 0.53 & 0.56 & 0.42 & 0.66 & 0.58 & 0.71 & 0.49 \\
\hline divorced & 0.22 & 0.08 & 0.20 & 0.12 & 0.13 & 0.10 & 0.19 \\
\hline low education & 0.14 & 0.13 & 0.11 & 0.50 & 0.30 & 0.38 & 0.16 \\
\hline high education & 0.32 & 0.31 & 0.22 & 0.13 & 0.34 & 0.22 & 0.26 \\
\hline employed & 0.78 & 0.81 & 0.71 & 0.67 & 0.80 & 0.63 & 0.73 \\
\hline self-employed & 0.11 & 0.07 & 0.07 & 0.21 & 0.05 & 0.11 & 0.09 \\
\hline retired & 0.00 & 0.00 & 0.00 & 0.01 & 0.00 & 0.01 & 0.00 \\
\hline income & 11.32 & 10.47 & 10.25 & 10.59 & 11.52 & 10.53 & 10.66 \\
\hline wealth (non-PR) & 3.61 & -0.25 & 2.66 & 6.81 & 7.86 & 6.86 & 3.35 \\
\hline 50 and over & US & Canada & Germany & Italy & Luxembourg & Spain & Total \\
\hline age & 64.89 & 63.94 & 67.28 & 67.12 & 64.69 & 65.54 & 66.41 \\
\hline male $(0 / 1)$ & 0.67 & 0.60 & 0.58 & 0.62 & 0.51 & 0.52 & 0.61 \\
\hline no. of children lt 18 & 0.36 & 0.04 & 0.08 & 0.12 & 0.19 & 0.05 & 0.16 \\
\hline $\mathrm{s} * 100$ & 35.60 & 40.41 & 48.17 & 40.56 & 35.82 & 29.67 & 42.84 \\
\hline $\mathrm{sp} * 100$ & 8.84 & 0.67 & 0.90 & 1.10 & 4.58 & 12.37 & 3.70 \\
\hline $\mathrm{cp} * 100$ & 39.12 & 54.91 & 45.78 & 50.32 & 36.62 & 28.61 & 43.54 \\
\hline $\mathrm{cpk} * 100$ & 16.44 & 3.64 & 4.02 & 8.01 & 22.98 & 29.35 & 9.67 \\
\hline married & 0.52 & 0.53 & 0.48 & 0.58 & 0.58 & 0.58 & 0.51 \\
\hline divorced & 0.41 & 0.01 & 0.43 & 0.33 & 0.34 & 0.34 & 0.40 \\
\hline low education & 0.17 & 0.32 & 0.19 & 0.74 & 0.46 & 0.70 & 0.25 \\
\hline high education & 0.30 & 0.20 & 0.20 & 0.08 & 0.22 & 0.14 & 0.22 \\
\hline employed & 0.40 & 0.37 & 0.24 & 0.16 & 0.24 & 0.19 & 0.28 \\
\hline self-employed & 0.11 & 0.06 & 0.05 & 0.10 & 0.03 & 0.07 & 0.07 \\
\hline retired & 0.47 & 0.48 & 0.50 & 0.68 & 0.43 & 0.39 & 0.50 \\
\hline income & 11.21 & 10.37 & 10.58 & 10.71 & 11.44 & 10.40 & 10.76 \\
\hline wealth (non-PR) & 8.53 & 4.97 & 5.88 & 8.13 & 9.46 & 8.99 & 6.93 \\
\hline
\end{tabular}

Note: S- singles; SP - single parents; CP -couples without kids; CPK - couples with kids. 
Table A.3: Coefficients from Distribution Regression at the median wealth variable level for households whose head is under 50 years of age in the US and Canada

\begin{tabular}{|c|c|c|c|c|c|c|}
\hline US & $\begin{array}{l}\text { (1) } \\
\text { tfa }\end{array}$ & $\begin{array}{l}\text { (2) } \\
\mathrm{nr}\end{array}$ & $\begin{array}{l}\text { (3) } \\
\text { ir }\end{array}$ & $\begin{array}{l}(4) \\
\text { mo }\end{array}$ & (5) & (6) \\
\hline age & $-0.061 * *$ & $0.089 * *$ & $-0.253 * * *$ & $-0.079 *$ & 0.039 & $0.086^{* * *}$ \\
\hline age2 & 0.036 & $-0.129 * *$ & $0.297 * * *$ & $0.168 * * *$ & -0.073 & $-0.091 * *$ \\
\hline male & -0.074 & 0.111 & -0.028 & $0.159^{*}$ & $-0.482 * * *$ & -0.041 \\
\hline child & $0.371 * * *$ & -0.070 & $0.331 * * *$ & -0.057 & $0.275^{* * *} *$ & $0.107 * * *$ \\
\hline low educ. & $0.925 * * *$ & 0.040 & -0.210 & $0.379 * * *$ & $0.495^{* *}$ & $0.216^{* * *}$ \\
\hline high educ. & $-0.796 * * *$ & $-0.637 * * *$ & $-0.579 * * *$ & $-0.088^{*}$ & $-0.639 * * *$ & $-0.233 * * *$ \\
\hline married & $-0.348 * * *$ & $0.135^{*}$ & $-0.437 * * *$ & 0.114 & $0.237 * *$ & $-0.361 * * *$ \\
\hline divorced & 0.067 & $0.429 * * *$ & $-0.332 * *$ & $0.266^{* * *}$ & $0.249 * *$ & $-0.229 * * *$ \\
\hline employed & $-0.471 * * *$ & 0.044 & 0.382 & $-0.643 * * *$ & 0.265 & $-0.162 *$ \\
\hline self-employed & $-0.269 * *$ & -0.097 & -0.093 & $-0.447 * * *$ & -0.044 & -0.034 \\
\hline retired & 0.024 & 0.228 & $0.604 *$ & $-0.645^{* *}$ & -0.244 & 0.091 \\
\hline income & $-0.253 * * *$ & $-0.450 * * *$ & $-0.183 * * *$ & $-0.097 * * *$ & $-0.074 * *$ & $-0.060 * * *$ \\
\hline other wealth & $-0.034 * * *$ & $-0.020 * * *$ & -0.005 & & $-0.068 * * *$ & \\
\hline Constant & $5.434 * * *$ & $3.776 * * *$ & $7.595 * * *$ & $14.102 * * *$ & 1.440 & -0.194 \\
\hline Observations & 8,581 & 6,025 & 2,090 & 5,170 & 3,637 & 6,716 \\
\hline Canada & $\mathrm{tfa}$ & $\mathrm{pr}$ & ir & $\mathrm{mg}$ & $\mathrm{ra}$ & nhd \\
\hline age & 0.043 & -0.122 & 0.109 & 0.057 & 0.063 & $0.202 * * *$ \\
\hline age2 & -0.069 & 0.155 & -0.126 & -0.019 & -0.093 & $-0.254 * *$ \\
\hline male & 0.088 & 0.006 & 0.151 & -0.001 & 0.227 & 0.156 \\
\hline child & $0.214 * *$ & -0.037 & -0.356 & 0.041 & -0.003 & -0.158 \\
\hline low educ. & $0.259^{*}$ & $0.519 * * *$ & 0.411 & 0.138 & 0.055 & 0.124 \\
\hline high educ. & $-0.375 * * *$ & $-0.384 * * *$ & -0.229 & $-0.194^{*}$ & -0.154 & $-0.183^{*}$ \\
\hline married & $-0.367 * * *$ & $-0.582 * * *$ & -0.003 & -0.217 & 0.317 & -0.175 \\
\hline divorced & 0.038 & -0.320 & 0.661 & -0.134 & $1.192 * * *$ & 0.087 \\
\hline employed & -0.135 & 0.266 & 0.119 & -0.186 & $1.465 * * *$ & -0.225 \\
\hline self-employed & -0.193 & -0.224 & -0.641 & 0.127 & $1.179 * * *$ & $-0.517 * *$ \\
\hline income & -0.147 & -0.203 & 0.021 & -0.027 & $-0.531 * * *$ & $-0.174 *$ \\
\hline other wealth & $-0.040 * * *$ & $-0.019 * * *$ & 0.003 & & $-0.050 * * *$ & \\
\hline Constant & 1.452 & $4.903 * *$ & -2.393 & $12.011 * * *$ & 3.477 & -1.657 \\
\hline Observations & 2,087 & 1,599 & 425 & 1,191 & 683 & 1,650 \\
\hline
\end{tabular}

Robust standard errors in parentheses

TFA is Total Financial Assets, RA is risky assets, PR is Principal Residence IR is Investment Real Estate, MG is Mortgage and NHD is Non-housing debt $* * * \mathrm{p}<0.01, * * \mathrm{p}<0.05, * \mathrm{p}<0.1$ 
Table A.4: Coefficients from Distribution Regression at the median wealth level for households whose head is under 50 years of age in Germany and Luxembourg

\begin{tabular}{|c|c|c|c|c|c|}
\hline Ger & $\begin{array}{l}\text { (1) } \\
\text { tfa }\end{array}$ & $\begin{array}{l}\text { (2) } \\
\mathrm{pr}\end{array}$ & $\begin{array}{l}\text { (3) } \\
\text { ir }\end{array}$ & $\begin{array}{l}(4) \\
m g\end{array}$ & $\begin{array}{l}\text { (5) } \\
\text { nhd }\end{array}$ \\
\hline age & $-0.094 * * *$ & $-0.259 * * *$ & 0.103 & $-0.097^{*}$ & $-0.145 * * *$ \\
\hline age2 & $0.097 * *$ & $0.315^{* * *}$ & -0.138 & $0.174 * * *$ & $0.179 * * *$ \\
\hline male & 0.034 & $-0.074^{*}$ & 0.066 & $-0.086^{*}$ & $-0.204 * * *$ \\
\hline child & $0.160 * * *$ & $-0.365 * * *$ & $0.210 * *$ & 0.035 & 0.009 \\
\hline low educ. & $0.389 * * *$ & $0.226 * * *$ & 0.171 & $-0.225 * * *$ & $-0.137 * *$ \\
\hline high educ. & $-0.501 * * *$ & $-0.197 * * *$ & $-0.276 * * *$ & $-0.140 * * *$ & 0.042 \\
\hline married & $-0.116^{* *}$ & $-0.545 * * *$ & -0.157 & $-0.362 * * *$ & $-0.353 * * *$ \\
\hline divorced & -0.014 & 0.038 & $-0.351 * * *$ & $-0.323 * * *$ & -0.047 \\
\hline employed & -0.070 & $-0.215 * * *$ & 0.015 & 0.028 & $0.234 * * *$ \\
\hline self-employed & $-0.289 * * *$ & $-0.233 * * *$ & 0.024 & 0.060 & $-0.301 * * *$ \\
\hline income & 0.005 & $0.015 * * *$ & 0.015 & -0.002 & $-0.019 * *$ \\
\hline other wealth & $-0.021 * * *$ & $-0.016 * * *$ & $-0.021 * * *$ & & \\
\hline Constant & $2.444 * * *$ & $6.024 * * *$ & -1.726 & $11.848 * * *$ & $3.293 * * *$ \\
\hline Observations & 13,315 & 9,395 & 2,870 & 7,430 & 7,575 \\
\hline Luxembourg & $\mathrm{tfa}$ & $\mathrm{pr}$ & ir & $\mathrm{mg}$ & nhd \\
\hline age & $-0.080 *$ & $-0.152 * * *$ & -0.169 & 0.036 & \\
\hline age2 & 0.078 & $0.152 * *$ & $0.273 *$ & 0.054 & \\
\hline male & $-0.163 * * *$ & -0.040 & $0.516^{* * *}$ & -0.038 & \\
\hline child & $0.304 * * *$ & 0.035 & $-0.461 * * *$ & $0.265 * * *$ & \\
\hline low educ. & $0.435 * * *$ & $0.371 * * *$ & $-0.383 * *$ & -0.074 & \\
\hline high educ. & $-0.316 * * *$ & 0.067 & $-0.467 * * *$ & $-0.384 * * *$ & \\
\hline married & $-0.189 * *$ & $-0.193 * *$ & $0.511 * *$ & -0.045 & \\
\hline divorced & $-0.350 * * *$ & $-0.254 * *$ & -0.339 & $-0.476 * * *$ & \\
\hline employed & $-0.217 * *$ & $0.180 * *$ & 0.165 & -0.041 & \\
\hline self-employed & 0.015 & -0.086 & -0.080 & 0.069 & \\
\hline income & $-0.102 * *$ & $-0.646 * * *$ & $0.443 * * *$ & 0.017 & \\
\hline other wealth & $-0.014 * * *$ & -0.008 & $-0.289 * * *$ & & \\
\hline Constant & $3.317 * * *$ & $11.115^{* * *}$ & $25.341 * * *$ & 1.639 & \\
\hline Observations & 6,068 & 5,256 & 2,272 & 4,635 & \\
\hline
\end{tabular}

Robust standard errors in parentheses

TFA is Total Financial Assets, RA is risky assets, PR is Principal Residence IR is Investment Real Estate, MG is Mortgage and NHD is Non-housing debt $* * * \mathrm{p}<0.01, * * \mathrm{p}<0.05, * \mathrm{p}<0.1$ 
Table A.5: Coefficients from Distribution Regression at the median wealth variable level for households whose head is under 50 years of age in Italy and Spain

\begin{tabular}{|c|c|c|c|c|c|c|}
\hline & (1) & (2) & (3) & (4) & (5) & (6) \\
\hline Italy & $\mathrm{tfa}$ & $\mathrm{pr}$ & ir & $\mathrm{mg}$ & ra & nhd \\
\hline age & 0.037 & -0.058 & $-0.430 * *$ & 0.229 & -0.247 & $0.251^{*}$ \\
\hline age2 & -0.062 & 0.057 & $0.525 * *$ & -0.207 & 0.303 & $-0.318 *$ \\
\hline male & -0.130 & -0.108 & -0.026 & -0.096 & -0.150 & -0.022 \\
\hline child & 0.072 & -0.049 & 0.127 & 0.054 & 0.362 & -0.040 \\
\hline low educ. & $0.450 * * *$ & $0.343 * * *$ & $0.505 * *$ & 0.078 & 0.114 & 0.025 \\
\hline high educ. & -0.074 & $-0.382 * * *$ & $-0.918 * * *$ & -0.226 & -0.151 & $-0.540 *$ \\
\hline married & $0.346 * *$ & 0.162 & -0.025 & -0.086 & 0.047 & -0.354 \\
\hline divorced & 0.230 & 0.249 & 0.269 & -0.555 & $-0.717 * *$ & -0.006 \\
\hline employed & $0.313^{*}$ & 0.095 & 0.358 & -0.414 & 0.049 & -0.151 \\
\hline self-employed & 0.166 & -0.046 & 0.295 & $-0.706 * *$ & -0.139 & -0.222 \\
\hline retired & 0.443 & 0.389 & & & & -0.541 \\
\hline incomei & $-0.910 * * *$ & $-0.156 * *$ & -0.038 & 0.076 & $-0.667 * * *$ & -0.035 \\
\hline other wealth & $-0.026 * * *$ & -0.011 & -0.016 & & 0.008 & \\
\hline Constant & $8.989 * * *$ & 3.185 & $8.941 * *$ & -1.499 & $12.266 * * *$ & -3.118 \\
\hline Observations & 2,001 & 1,476 & 400 & 519 & 430 & 584 \\
\hline Spain & $\mathrm{tfa}$ & $\mathrm{pr}$ & ir & $\mathrm{mg}$ & $\mathrm{ra}$ & nhd \\
\hline age & 0.089 & 0.082 & $-0.381 * *$ & 0.186 & 0.388 & 0.097 \\
\hline age2 & -0.137 & -0.147 & $0.458 * *$ & -0.196 & -0.495 & -0.134 \\
\hline male & $-0.215 * *$ & 0.087 & -0.031 & -0.091 & -0.014 & $0.461 * * *$ \\
\hline child & $0.228 * *$ & -0.130 & 0.229 & 0.056 & 0.230 & 0.080 \\
\hline low educ. & $0.431 * * *$ & $0.480 * * *$ & 0.294 & 0.232 & -0.646 & 0.269 \\
\hline high educ. & $-0.344 * * *$ & $-0.255^{*}$ & $-0.380 *$ & 0.032 & 0.060 & -0.043 \\
\hline married & -0.169 & -0.074 & 0.113 & $0.474 * *$ & 0.112 & -0.328 \\
\hline divorced & $0.327 *$ & -0.084 & 0.012 & 0.055 & -0.606 & 0.280 \\
\hline employed & $-0.204 *$ & $-0.259 * *$ & -0.248 & -0.080 & 1.978 & $-0.411 * *$ \\
\hline self-employed & -0.066 & -0.106 & $-0.811 * *$ & 0.020 & 1.123 & $-0.968 * * *$ \\
\hline retired & 0.445 & -0.003 & $-2.083 * * *$ & & & $-1.321 * *$ \\
\hline income & -0.026 & -0.013 & -0.034 & 0.006 & -0.241 & 0.039 \\
\hline other wealth & $-0.043 * * *$ & -0.003 & $0.045^{* * *}$ & & -0.152 & \\
\hline Constant & -0.547 & -0.728 & $7.760 * *$ & 1.466 & -4.844 & -1.749 \\
\hline Observations & 1,698 & 1,417 & 637 & 741 & 90 & 514 \\
\hline
\end{tabular}

Robust standard errors in parentheses

TFA is Total Financial Assets, RA is risky assets, PR is Principal Residence IR is Investment Real Estate, MG is Mortgage and NHD is Non-housing debt $* * * \mathrm{p}<0.01, * * \mathrm{p}<0.05, * \mathrm{p}<0.1$ 